\title{
The Impact of Cooperation with Poland on Lithuania's Energy Security
}

\begin{abstract}
In 2006, when the Polish company PKN Orlen acquired the controlling stake in the oil refinery Mazeikiu Nafta, Lithuanian and Polish politicians started elaborating on a new phase in the bilateral strategic partnership. Enthusiasm about the future of energy cooperation naturally raises the question: how strongly founded it is? More than ten years ago, a strategic partnership with Poland was nothing more than declaration, why did it happen to become the main tool of energy security? This article analyzes the cooperation between Lithuania and Poland in different energy sectors; evaluates its strengths, weaknesses, opportunities, and threats; and predicts its outcomes to Lithuania's energy security. The model of interaction between geo-energetic actors, which describes their interests and relations, was applied to this research. It is concluded that the strategic energy partnership is hardly feasible due to different geo-energetic functions of Poland and those of Lithuania. Therefore it is suggested to avoid overvaluation of bilateral cooperation and reconsider reliance of Lithuania's energy security upon energy relations with Poland.
\end{abstract}

\section{Introduction}

The years 2006 and 2007, as no previous years, were productive of events that had a lot to do with the consequences on Lithuania's energy security. After January 2006, when the supply of natural gas from Russia through Ukraine to Europe was cut off, concerns about energy security arouse in European Union. In the beginning of 2006 the Prime Ministers of three Baltic States agreed to cooperate while implementing the project of nuclear power plant (NPP) in Lithuania. In the middle of 2006 the supply of oil to Lithuania was cut off as a consequence of an accident in the Druzhba oil pipeline. During the same year, the Polish company PKN Orlen became an owner of Lithuania's oil refinery Mazeikiu Nafta. At the end of 2006 Poland declared its willingness to join the three Baltic States in the NPP project. In the winter of 2006-2007, because of conflict between Russia and Belarus and the threat of natural gas cut-off once

\footnotetext{
${ }^{*}$ Kęstutis Budrys - Ph.D. candidate of Institute of International Relations and Political Science of Vilnius University. Address: Vokiečių 10, LT- 01130 Vilnius, Lithuania, tel. +370-5-2514130.
} 
again occurred to EU. In the beginning of 2007 the Parliament of Lithuania confirmed a new National Energy Strategy, which outlines the main directions for the strengthening of Lithuania's energy security. In 2007 the feasibility study of the Power Bridge between Lithuania and Poland was completed, and Klaipedos Nafta became the shareholder of a company that will build OdessaBrody-Plock oil pipeline. The greater part of these and other events are linked to Lithuania's relations with foreign countries and energy companies.

More intense cooperation with Poland is one of most significant changes in Lithuania's foreign and energy from 2006. For more than 10 years, Poland was considered as Lithuania's 'gates' to Western Europe and opportunity to increase energy security. A similar position dominated all the National Security Strategies beginning from 1994. However all attempts to strengthen Poland's interests expand connections with Lithuania were less successful than expected. A major push for bilateral cooperation in the energy sector was the purchase of Mazeikiu Nafta portfolio by PKN Orlen in 2006. The change of shareholders invoked hopes that the relations between Lithuania and Poland would grow to the next stage of new cooperation and real strategic partnership. In 2007 the President of the Republic of Lithuania in his State of the Nation supported efficient cooperation with neighbouring countries and positive changes in 2006 - the sale of Mazeikiu Nafta and agreements with Poland on connecting natural gas and power grids. ${ }^{1}$ The Government of the Republic of Lithuania in its Report on Activities in 2006 to the Seimas concluded that "the strategic partnership of Lithuania and Poland is increasingly developing" and it is "proven by particular projects." 2 The same opinion - that a strategic partnership provides an increasing number of practical examples - is expressed by the representatives of Poland as well. ${ }^{3}$ On January 18, 2007 the Seimas passed the Resolution on the Approval of the National Energy Strategy (National Energy Strategy). The National Energy Strategy states, that the mission of the state is "to develop the strategic partnership of Lithuania and the Baltic States and Poland as well as closer cooperation in all energy sectors (especially electricity, gas and oil sectors)." ${ }^{4}$ In the Spring of 2007 the Prime Minister of Lithuania Gediminas Kirkilas and Prime Minister of Poland Jaroslaw Kaczynski signed

\footnotetext{
${ }^{1}$ State of the Nation Address to the Seimas of the Republic of Lithuania by H.E. Mr. Valdas Adamkus, President of the Republic of Lithuania (2007), http://www.president.lt/file/state_of_the_nation2007.pdf, 20070826.

${ }^{2}$ Government of the Republic of Lithuania, Nutarimas del Lietuvos Respublikos Vyriausybès 2006 metu veiklos ataskaitos pateikimo Lietuvos Respublikos Seimui [Resolution on submission of the report on activities of the Government of the Republic of Lithuania in 2006 to the Seimas of the Republic of Lithuania], No. 307, 200703 21, http://www.lrv.lt/14_vyr_dok/2006_veikl_atask.pdf, 20070904 (in Lithuanian).

${ }^{3}$ Ministry of the Foreign Affairs of the Republic of Lithuania, Lietuvos ir Lenkijos strategine partneryste igauna vis daugiau praktiniu pavyzdžiu [Strategic partnership of Lithuania and Poland gets even more examples of practical cooperation], 200606 13, http://www.urm.lt/index.php?1080257421, 20070806 (in Lithuanian).

${ }^{4}$ Seimas of the Republic of Lithuania, Resolution on the Approval of the National Energy Strategy, No. X-1046, 200701 18, http://www3.lrs.lt/pls/inter3/dokpaieska.showdoc_1?p_id=292522, 20070901.
} 
a joint communiqué, where they expressed their support for: the construction of a nuclear power plant in Lithuania and power grid between Poland and Lithuania; an EU common energy policy; an opportunity to connect the gas pipelines of Lithuania and Poland; and a determination to solve the problem of the renewal of oil supply to Lithuania..$^{5}$ Ambitions of such a wide cooperation inspired some high ranked Lithuanian politicians to initiate discussions on the creation of the 'Energy Rzeczpospolita' - the guarantee of region's energy security. ${ }^{6}$

This article analyzes the opportunities for cooperation in the energy field between Lithuania and Poland as well as its expected outcomes for Lithuania's energy security. The model of relations between geo-energetic actors is applied. The model describes the main interests of geo-energetic actors and priorities of their energy security policies. The natural gas, electricity and oil sectors of Lithuania and Poland are analyzed and joint energy projects assessed from the point of energy security in the article. It should be mentioned that the following topics were not a subject of analysis: relations between Poland and Lithuania in other than energy fields; internal energy policies of both countries if they are not directly related to Lithuania and Poland respectively; Lithuania's relations in the energy field with other countries. It is concluded that prospects of energy cooperation between Lithuania and Poland are limited. Therefore creation of the 'Energy Rzeczpospolita' is impossible or even unnecessary.

\section{Dependence of the Energy Security on Geo-energetic Position}

\subsection{Relations among Geo-energetic Actors}

Energy security does not have one definition. The concept of energy security varies because of the position of geo-energetic actor (the state). The position of geo-energetic actor depends on the place of its energy sector in a chain of the cycle of energy resources: extraction/generation - transportation/refining consumption. The dominant activity in a separate energy sector (natural gas, oil, electricity, coal) can be: extraction of energy resources (natural gas, oil), production (electricity), transportation of energy resources (transit), refining

\footnotetext{
${ }^{5}$ Alfa.lt, Lietuva ir Lenkija spartina energetini bendradarbiavima [Lithuania and Poland accelerate energy cooperation], 200703 03, http://alfa.lt/straipsnis/127321, 20070805 (in Lithuanian).

${ }^{6}$ For example, see Tèvynès Sajunga, Rusijos sulaikymo strategija. Rusijos įtakos Lietuvoje mažinimo planas [Russia's containment strategy. Plan of reducing Russia's influence in Lithuania], 20070509 , http://www.visuomenei.lt/modules/document_publisher/documents/2/Rusijos\%20sulaikymo\%20strategijo s\%20projektas\%2007\%2005\%2010.doc, 20070903 (in Lithuanian). Also Kubilius A., "Mažeikiu nafta" ir strateginè partnerystè su Lenkija [Mazeikiu Nafta and strategic partnership with Poland], 200612 18, http://www3.lrs.lt/pls/inter/w5_show?p_r=4932\&p_d=62373\&p_k=1, 20070903 (in Lithuanian).
} 
(liquefaction of natural gas, oil refining), and consumption of energy resources (distribution nets, storage facilities). The dominant activity of a separate energy sector depends upon, firstly, the dominant infrastructure of the energy sector - extraction, production, transportation, refining or consumption. Due to the fact that the energy infrastructure may not be exploited (for example, oil pipeline to Lithuania) - the flows of energy resources are the second factor of the dominant activity: export (extraction), transit (transportation), export of products (refining) or import (consumption). Commonly one state fulfils different functions in different energy sectors. The dominant function in all energy sectors or the function in the sector of dominant energy resource determines the function of whole energy field in the geo-energetic scheme - its geo-energetic position. The state's function in the geo-energetic scheme is directly related to its geo-economic position.

According to the dominant activity in the different energy sectors the states can be divided to suppliers, transporters and/or refiners, and consumers. This division is conditional, because one state can fulfil all functions at once. In such cases the dominant function is attributed. It should be mentioned that the dominant function can vary as a consequence of both changes in infrastructure (for example, because of construction of new oil export terminal) and changes in the flows of energy resources. Relations between different geo-energetic actors depends on, first, the geo-energetic nature of actor and, second, the intensity of interrelations. The intensity of interrelations depends upon the connections of the energy infrastructure as well as the bilateral flows of energy resources.

The relations between geo-energetic actors can be divided into the following groups: relations among suppliers; relations among transporters/refiners; relations among consumers; relations between suppliers and transporters/refiners; relations between suppliers and consumers; and, finely, relations between transporters/refiners and consumers. Interrelations between the different geoenergetic actors are meaningful in a geo-energetic analysis, when they can be described as interdependence-situation, when one geo-energetic actor cannot avoid the services of other geo-energetic actor without increase of threats to its energy security in the short term. For example, Lithuania cannot disrupt the supply of natural gas from Russia through Belarus, because the capacities of natural gas import from Latvia are insufficient, therefore such a move would threaten Lithuania's energy security. Similarly, Lithuania cannot refuse to buy natural gas from Russia, because only Gazprom supplies natural gas to Lithuania through the existing gas pipelines. Eventually, Lithuania (consumer) depends both on Belarus (transporter) and Russia (supplier). Interrelations among the same geo-energetic actors are meaningful in geo-energetic analysis, when they are connected by interdependence with other geo-energetic actor(s) (for example, dependence of two or more suppliers from the same consumer or the group of consumers). 
Table 1. Interrelations between Geo-energetic Actors

\begin{tabular}{|c|c|c|c|c|}
\hline \multicolumn{2}{|c|}{$\begin{array}{l}\text { Object } \\
\text { Subject }\end{array}$} & Supplier & Transporter/Refiner & Consumer \\
\hline \multirow{5}{*}{ के } & 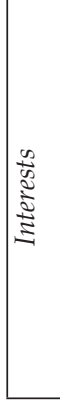 & $\begin{array}{l}\text { Avoidance of } \\
\text { competition for con- } \\
\text { sumers; avoidance } \\
\text { of competition for } \\
\text { transit countries }\end{array}$ & $\begin{array}{l}\text { Avoidance of transit countries } \\
\text { and refiners; guarantees of stable } \\
\text { supply; takeover of the control of } \\
\text { transit infrastructure and preven- } \\
\text { tion of any impact by transporter/ } \\
\text { refiner on supplier; guarantees of } \\
\text { favourable conditions of supply; } \\
\text { in the case takeover of the control } \\
\text { of transit infrastructure is unsuc- } \\
\text { cessful - diversification of supply } \\
\text { routes or avoidance of transporter; } \\
\text { takeover of the control of refining }\end{array}$ & $\begin{array}{l}\text { Monopolization of } \\
\text { supply for different } \\
\text { consumers; diversifica- } \\
\text { tion of export markets; } \\
\text { increase of depend- } \\
\text { ence of consumers on } \\
\text { supplier; expansion } \\
\text { of influence in the } \\
\text { distribution of energy } \\
\text { resources }\end{array}$ \\
\hline & \multicolumn{4}{|c|}{ Equal Actor } \\
\hline & 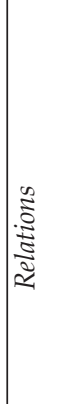 & $\begin{array}{l}\quad \text { Competition } \\
\text { Competition for } \\
\text { consumer mar- } \\
\text { kets, access to the } \\
\text { infrastructure of } \\
\text { transportation and } \\
\text { refining }\end{array}$ & $\begin{array}{l}\text { Cooperation } \\
\text { Supplier is dependent on transit } \\
\text { infrastructure that transports } \\
\text { energy resources to consumers. } \\
\text { Both supplier and transporter are } \\
\text { interested in stable supply, transit, } \\
\text { and cooperation with consumers. } \\
\text { Refiners are dependent on supply. } \\
\text { Relations between suppliers and } \\
\text { refiners develops in the same } \\
\text { way as between suppliers and } \\
\text { consumers. }\end{array}$ & $\begin{array}{l}\quad \text { Cooperation } \\
\text { Supplier and consumer } \\
\text { are interdependent. } \\
\text { Supplier and consumer } \\
\text { are both interested in } \\
\text { stable supply trough } \\
\text { transit countries, there- } \\
\text { fore expands diversity } \\
\text { of supply routes. Com- } \\
\text { petition for access to } \\
\text { refining infrastructure. }\end{array}$ \\
\hline & \multicolumn{4}{|c|}{ Dominant Actor } \\
\hline & 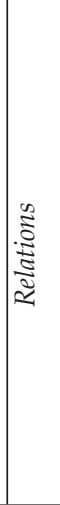 & $\begin{array}{l}\text { Takeover of the } \\
\text { Control } \\
\text { Fulfilment of all } \\
\text { interests }\end{array}$ & $\begin{array}{l}\text { Takeover of the Control } \\
\text { Fulfilment of all interests }\end{array}$ & $\begin{array}{l}\quad \text { Increase } \\
\quad \text { of Dependence } \\
\text { Supplier limits capa- } \\
\text { bilities of consumer } \\
\text { to diversify supply; } \\
\text { increases consumer's } \\
\text { dependence and mo- } \\
\text { nopolizes supply. The } \\
\text { latter allows to guaran- } \\
\text { tee the most favourable } \\
\text { price and conditions } \\
\text { of supply as well as to } \\
\text { expand influence in the } \\
\text { distribution of energy } \\
\text { resources }\end{array}$ \\
\hline
\end{tabular}




\begin{tabular}{|c|c|c|c|c|}
\hline \multirow{5}{*}{ 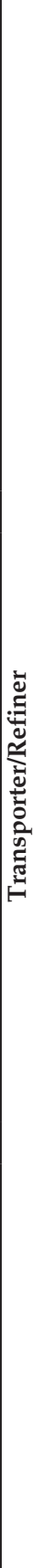 } & 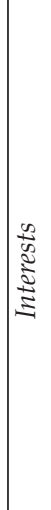 & $\begin{array}{l}\text { Increase of influ- } \\
\text { ence in the trade of } \\
\text { energy resources be- } \\
\text { tween suppliers and } \\
\text { consumers; limita- } \\
\text { tion of suppliers ca- } \\
\text { pabilities to develop } \\
\text { refining; limitation } \\
\text { of suppliers capabili- } \\
\text { ties to diversify the } \\
\text { routes of supply } \\
\text { - increase of suppli- } \\
\text { ers' dependence on } \\
\text { transit and refining } \\
\text { infrastructure }\end{array}$ & $\begin{array}{l}\text { Monopolization of transit and re- } \\
\text { fining; elimination of competitors } \\
\text { by takeover of their infrastructure, } \\
\text { expansion of transit capabilities; } \\
\text { prevention of close cooperation } \\
\text { between other transporters/re- } \\
\text { finers and suppliers, and/or } \\
\text { consumers, if this cooperation can } \\
\text { decrease actors importance }\end{array}$ & $\begin{array}{l}\text { Increase of influence } \\
\text { in the trade of energy } \\
\text { resources between sup- } \\
\text { pliers and consumers; } \\
\text { expansion of export } \\
\text { markets of refined } \\
\text { energy products; pre- } \\
\text { vention of consumers } \\
\text { capabilities to develop } \\
\text { refining; prevention of } \\
\text { consumers capabilities } \\
\text { to diversify supply } \\
\text { routes - increase of } \\
\text { consumers' depend- } \\
\text { ence }\end{array}$ \\
\hline & \multicolumn{4}{|c|}{ Equal Actor } \\
\hline & $\mid \frac{\frac{a}{2}}{\frac{0}{a}}$ & $\begin{array}{l}\quad \text { Cooperation } \\
\text { Supplier depends } \\
\text { on transit infrastruc- } \\
\text { ture, through which } \\
\text { energy resources } \\
\text { reaches consum- } \\
\text { ers. Both supplier } \\
\text { and transporter are } \\
\text { interested in stable } \\
\text { supply, transit, and } \\
\text { cooperation with } \\
\text { consumers. Refiners } \\
\text { are dependent on } \\
\text { supply. Relations } \\
\text { between suppliers } \\
\text { and refiners devel- } \\
\text { ops in the same way } \\
\text { as between suppliers } \\
\text { and consumers }\end{array}$ & $\begin{array}{l}\text { Competition } \\
\text { Transporters and/or refiners com- } \\
\text { petes among themselves for tran- } \\
\text { sit and/or refining of the energy } \\
\text { resources from the same suppliers } \\
\text { or for the same consumers } \\
\end{array}$ & \begin{tabular}{l}
\multicolumn{1}{c}{ Cooperation } \\
Consumer depends on \\
transit infrastructure \\
and stable supply. \\
Transporter looks for \\
stable and long term \\
relations
\end{tabular} \\
\hline & \multicolumn{4}{|c|}{ Dominant Actor } \\
\hline & 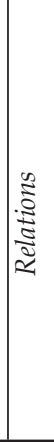 & \begin{tabular}{l}
\multicolumn{1}{c}{$\begin{array}{c}\text { Increase } \\
\text { of dependence }\end{array}$} \\
Transporter and/or \\
refiner limits capa- \\
bilities of supplier \\
to diversify supply \\
routes and markets, \\
if this can threaten \\
its importance
\end{tabular} & $\begin{array}{l}\text { Takeover of the Control } \\
\text { Fulfilment of all interests }\end{array}$ & $\begin{array}{l}\quad \text { Increase } \\
\quad \text { of Dependence } \\
\text { Transporter and/or } \\
\text { refiner limits capa- } \\
\text { bilities of consumer } \\
\text { to diversify supply } \\
\text { routes and suppliers, } \\
\text { if this can threaten its } \\
\text { importance. In the field } \\
\text { of refining of energy } \\
\text { resources relations are } \\
\text { the same as between } \\
\text { supplier and consumer }\end{array}$ \\
\hline
\end{tabular}




\begin{tabular}{|c|c|c|c|c|}
\hline & 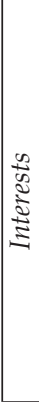 & $\begin{array}{l}\text { Favourable price and } \\
\text { conditions of stable } \\
\text { supply; increase of } \\
\text { supplier's depend- } \\
\text { ence; takeover of the } \\
\text { control of extraction } \\
\text { and production }\end{array}$ & $\begin{array}{l}\text { Avoidance of transit countries } \\
\text { and refiners; guarantees of stable } \\
\text { supply; takeover of the control of } \\
\text { transit infrastructure and preven- } \\
\text { tion of any impact by transporter / } \\
\text { refiner on consumer; guarantees of } \\
\text { favourable conditions of supply; } \\
\text { in the case takeover of the control } \\
\text { of transit infrastructure is unsuc- } \\
\text { cessful - diversification of supply } \\
\text { routes or avoidance of transporter; } \\
\text { takeover of the control of refining }\end{array}$ & $\begin{array}{l}\text { Avoidance of the com- } \\
\text { petition for suppliers; } \\
\text { avoidance of the com- } \\
\text { petition for transit and } \\
\text { refining - favourable } \\
\text { conditions of supply }\end{array}$ \\
\hline \multirow{4}{*}{ 离 } & \multicolumn{4}{|c|}{ Equal Actor } \\
\hline & 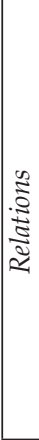 & $\begin{array}{l}\quad \text { Cooperation } \\
\text { Supplier and con- } \\
\text { sumer are interde- } \\
\text { pendent. Supplier } \\
\text { and consumer are } \\
\text { interested in stable } \\
\text { supply through tran- } \\
\text { sit countries, there- } \\
\text { fore they expand the } \\
\text { diversity of transit } \\
\text { routes. Competition } \\
\text { for access to refining } \\
\text { infrastructure }\end{array}$ & $\begin{array}{l}\text { Cooperation } \\
\text { Consumer is dependent on transit } \\
\text { infrastructure and stable supply, } \\
\text { therefore looks for stable and long } \\
\text { term relations }\end{array}$ & $\begin{array}{l}\quad \text { Competition } \\
\text { Consumers compete } \\
\text { for suppliers, routes } \\
\text { of supply of energy } \\
\text { resources and refining }\end{array}$ \\
\hline & \multicolumn{4}{|c|}{ Dominant Actor } \\
\hline & $\frac{\sqrt{2}}{\frac{2}{0}}$ & $\begin{array}{c}\text { Takeover } \\
\text { of the Control } \\
\text { Fulfilment of all } \\
\text { interests }\end{array}$ & $\begin{array}{l}\text { Takeover of the Control } \\
\text { Fulfilment of all interests }\end{array}$ & \begin{tabular}{l}
\multicolumn{1}{c}{ Takeover } \\
of the Control \\
Fulfilment of all \\
interests
\end{tabular} \\
\hline
\end{tabular}

As it is seen in Table 1, the relations between geo-energetic actors can be competition, cooperation, increase of the dependence, and takeover of the control. Competition is common among equal actors and the same geo-energetic actors (among suppliers, transporters, consumers), for example: competition between Iran and Russia for access to EU natural gas market; competition between Austria and Hungary for the transit of natural gas to Western Europe; competition between India and China for supply of energy resources from Middle East. Cooperation is feasible between equal, but different type (suppliers, transporters/refiners, consumers) geo-energetic actors, for example: cooperation between Iran and China in the field of oil supply; cooperation between Turkey and Azerbaijan in oil supply to Western Europe and the United States. When all three different types of geo-energetic actors cooperate, geo-energetic region, which encompasses whole cycle of the energy resources, may evolve (for the moment Western part of Eurasia is the only place, where such a region could be formed). However, the geo-energetic region should involve only equal actors, because otherwise it would be nondurable. The relations between actors 
of different sizes can be increased in relation to dependence or takeover of the control. The increase of vulnerability and decrease of independence are the outcomes of an increase of dependence, for example, Lithuania's dependence on the only supplier of natural gas and increased vulnerability to Russia's natural gas politics. The loss of geo-energetic subjectivity, in particular to the energy sector (or the whole energy field) is an outcome of the takeover of the control. Takeover of the control allows an actor to fulfil its interests, which are determined by its geo-energetic features. This is the reason why the overwhelming majority of the governments try to control takeovers in the energy field. It is common to define energy companies as strategic, because of their importance both to energy and national security.

\subsection{Criteria of Energy Security}

Energy security supposes the minimization of negative changes in the conditions of supply of energy resources. Energy security in the relation to other geo-energetic actors is associated with independence, diversification, flexibility, and stability. A more specific definition of energy security depends on the geoenergetic type of particular energy industry. Energy security for suppliers is the supply of diversified energy resources to diversified and stable markets through diversified routes with favourable conditions and the price. Energy security for consumers is the import of diversified energy resources from diversified and stable suppliers through diversified routes with favourable conditions and the price. Energy security for transporters and refiners is the transportation and refining of diversified energy resources from diversified and stable suppliers to diversified and stable consumers with favourable conditions and the price. Apart from stability and the diversification of energy resources (dependence on one energy resource - undiversified energy mix) all geo-energetic actors look for the avoidance of external monopolization and vertical integration of their energy sectors.

Lithuania's energy security is associated more with foreign relations than internal politics. An example can be the National Energy Strategy. ${ }^{7}$ Within the framework of the National Energy Strategy, the ensuring of energy security is based on the following provisions:

- Energy security is an integral part of national security;

- Ensuring of energy security requires a predictable, reliable, economically acceptable and environment-friendly energy supply;

- Energy security covers the totality of the conditions ensuring the diversity of traditional and renewable primary sources of energy, diversity and security of energy supply and independence from dictate of a monopolistic supplier, availability of energy to the consumer at acceptable prices in a competitive energy market;

${ }^{7}$ Resolution on the Approval of the National Energy Strategy (note 4). 
- Lithuania links its energy security to the integration of the country's energy systems into EU energy systems and with an efficient EU and national energy policy, which should ensure that Lithuania's energy security is on a par with that of other EU states.

Seeking to implement the strategic tasks of energy security, the National Energy Strategy highlights the role of Poland. The purpose is to foresee the likely outcomes of cooperation with Poland to Lithuania's energy security, first, the geo-energetic types of Lithuania's and Poland's energy sectors are evaluated. Second, the potential relations with Poland in different energy sectors are analyzed. Third, different types of relations are identified. Fourth, the consequences to Lithuania's energy security are assessed.

\section{Relations between Lithuania and Poland in the Natural Gas Sector}

\subsection{Dependence of Lithuania and Poland on Imports from Russia}

In their study, the EU Standards for Energy Security of Supply - Updates on the Crisis Capability Index and the Supply/Demand Index Quantification for EU-27 Energy Research Centre of the Netherlands and Clingendael International Energy Programme assess inter alia Supply/Demand Index - quantitative indicator, which is covering full energy supply/demand balances. ${ }^{8}$ The Supply/Demand Index (S/D index) assesses energy security of supply in the medium and longer run and it covers final energy demand, energy conversion and transport and primary energy resources ${ }^{9}$ (Crisis Capability Index, which shows the risk of sudden unforeseen short term supply interruptions and the capability to manage them, was not assessed for all EU member states). Lithuania and Poland have different S/D indexes. In 2005 Lithuania's index was sixth lowest in EU -45 , while the one of Poland is higher than EU average (56) -60. The authors of the study also had assessed EU energy supply/demand trends and calculated S/D index for 2020. It can be concluded that Lithuania's position will remain in 2020 (46), while Poland will exceed EU average (53) - 55. This assessment shows different vulnerabilities of energy sectors of Lithuania and Poland and less favourable position of Lithuania in the flows of energy resources in EU.

\footnotetext{
${ }^{8}$ Scheepers M., Seebregts A., Jong J., Maters H., EU Standards for Energy Security of Supply. Updates on the Crisis Capability Index and the Supply/Demand Index Quantification for EU-27, http://www.ecn. nl/docs/library/report/2007/e07004.pdf, 20070816.

${ }^{9} \mathrm{Ibidem}$ (note 8).
} 


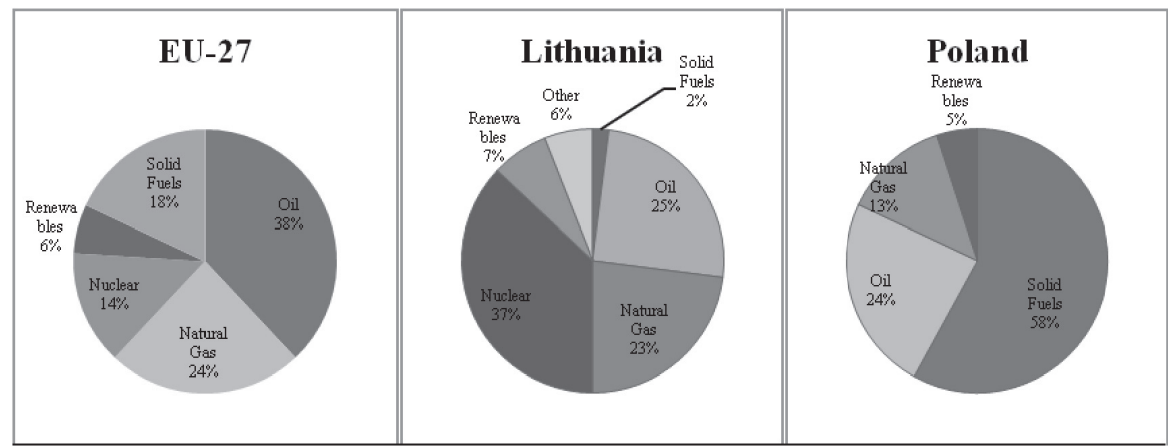

Figure 1. Total Primary Energy Supply in EU-27, Lithuania, and Poland in 2004 ${ }^{10}$

In 2006, Russia's natural gas constituted 39\% of all EU natural gas imports. Russia's share continually grows, despite of slight decrease in 2006 (1\% in comparison with 2005, when it was 40\%). ${ }^{11}$ However the latter drop should be considered as a consequence of a relatively warm winter and the subsequent decrease of total natural gas consumption in 2006 (5.4\%). The EU's share in Russia's exports of natural gas is $54 \%{ }^{12}$, therefore it is not quite true to say that EU is dependent on Russia - Russia and the EU are rather interdependent.

Table 2. Natural Gas Dependency of Lithuania and Poland in mtoe ${ }^{13}$

\begin{tabular}{|l|l|r|r|}
\hline \multicolumn{2}{|c|}{} & \multicolumn{1}{|c|}{ Lithuania } & Poland \\
\hline \multirow{4}{*}{ Primary production } & 2005 & 0 & 4.3 \\
\cline { 2 - 4 } & 2006 & 0 & 4.3 \\
\cline { 2 - 4 } & $2006 / 2005 \%$ & 0 & -0.7 \\
\hline \multirow{4}{*}{ Total imports } & 2005 & 2.8 & 9.5 \\
\cline { 2 - 5 } & 2006 & 2.8 & 9.9 \\
\cline { 2 - 5 } & $2006 / 2005 \%$ & -1.6 & 4.8 \\
\hline \multirow{3}{*}{$\begin{array}{l}\text { Resources (primary production + total } \\
\text { imports) }\end{array}$} & 2005 & 2.8 & 13.8 \\
\cline { 2 - 5 } & 2006 & 2.8 & 14.2 \\
\cline { 2 - 5 } & $2006 / 2005 \%$ & -1.6 & 3.1 \\
\hline
\end{tabular}

${ }^{10}$ Commission of the European Communities, Commission Staff Working Document. EU Energy Policy Data, SEC(2007)12, 200710 10, http://ec.europa.eu/energy/energy_policy/doc/02_eu_energy_policy_ data_en.pdf, 20070810.

${ }^{11}$ Jimenez A., "Statistical Aspects of the Natural Gas Economy in 2006", Eurostat Data in Focus, 14/2007, http://epp.eurostat.ec.europa.eu/cache/ITY_OFFPUB/KS-QA-07-014/EN/KS-QA-07-014EN.PDF, 20070810.

${ }^{12}$ In 2006 Russia produced 556 billion cubic meters of natural gas, exported -262.5 billion cubic meters. Natural gas exports to EU constituted 142 billion cubic meters. OAO Gazprom, Annual Report 2006, http://www.gazprom.com/documents/Report_Eng.pdf, 20070715.

${ }^{13}$ Jiménez (note 11). 


\begin{tabular}{|l|l|r|r|}
\hline \multirow{2}{*}{ Stock change } & 2005 & 0 & -0.2 \\
\cline { 2 - 4 } & 2006 & 0 & -0.5 \\
\hline \multirow{4}{*}{ Total exports } & 2005 & 0 & 0 \\
\cline { 2 - 4 } & 2006 & 0 & 0 \\
\cline { 2 - 4 } & $\begin{array}{l}2006 / 2005 \\
\%\end{array}$ & 0 & 0.2 \\
\hline \multirow{3}{*}{$\begin{array}{l}\text { Gross inland consumption (resources }+ \\
\text { stock change - total exports) }\end{array}$} & 2005 & 2.8 & 13.5 \\
\cline { 2 - 4 } & 2006 & 2.8 & 13.7 \\
\cline { 2 - 4 } & $\begin{array}{l}2006 / 2005 \\
\%\end{array}$ & -1.6 & 1.1 \\
\hline $\begin{array}{l}\text { Energy dependency (total imports - total } \\
\text { exports)/gross inland consumption }\end{array}$ & $2005 \%$ & 100 & 69.7 \\
\cline { 2 - 4 } & $2006 \%$ & 100 & 72.2 \\
\hline
\end{tabular}

The situation surrounding the natural gas sectors in Lithuania and Poland is different of that in EU. In 2006 Poland's natural gas dependency on imports was $72.2 \%$, Lithuania's - 100\% (see Table 2). However the assessment of dependency is an insufficient indicator, it is suggested to evaluate additionally, first, the diversification of imports, second, the share of imported energy resources in the energy mix, and, third, the consumers importance to the supplier (supplier's dependence on consumer). EU natural gas dependence on imports is $61 \%^{14}$, however imports are diversified (see Picture 2) - Russia's share is $39 \%$. Natural gas constitutes $24 \%$ in total primary energy supply (see Picture 1). Moreover, EU market for Russia is of strategic importance $-54 \%$ of all natural gas exports go to EU.

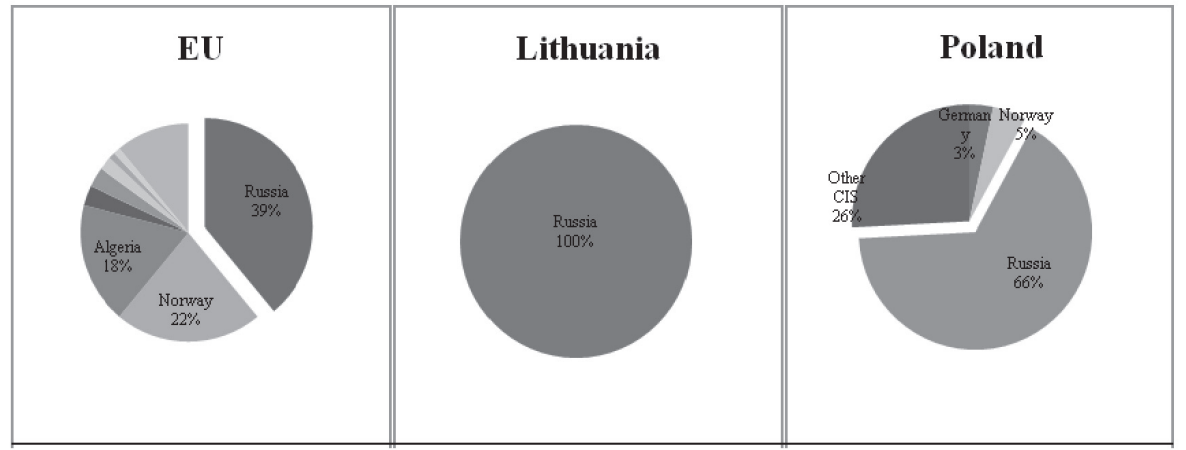

Figure 2. Natural Gas Imports in EU, Lithuania, and Poland in 2006 ${ }^{15}$

\footnotetext{
${ }^{14}$ Ibidem.

${ }^{15}$ Ibidem. Also see The BP Statistical Review of World Energy 2007, http://www.bp.com/liveassets/bp_internet/globalbp/globalbp_uk_english/reports_and_publications/statistical_energy_review_2007/STAGING/local_assets/downloads/spreadsheets/statistical_review_full_report_workbook_2007.xls, 20070612.
} 
Poland's natural gas imports are less diversified than in the EU - Russia's share constitutes $66 \%$. However natural gas makes barely $13 \%$ in total primary energy supply. Therefore Poland's energy sector is less dependent on natural gas imports from Russia. On the other hand, situation in Poland's natural gas industry will change in forthcoming years. Firstly, due to environmental requirements consumption of solid fuels should be reduced in Poland. In 2004, it was predicted that consumption of natural gas would reach 18.5-19.3 billion cubic meters $(\mathrm{bcm})$ in $2010 .{ }^{16}$ Second, the imports of natural gas will grow as an outcome of stable production, decreasing reserves, and increasing consumption (see Picture 3). It can be estimated that Poland's dependence on natural gas imports will grow in general and from Russia in particular.

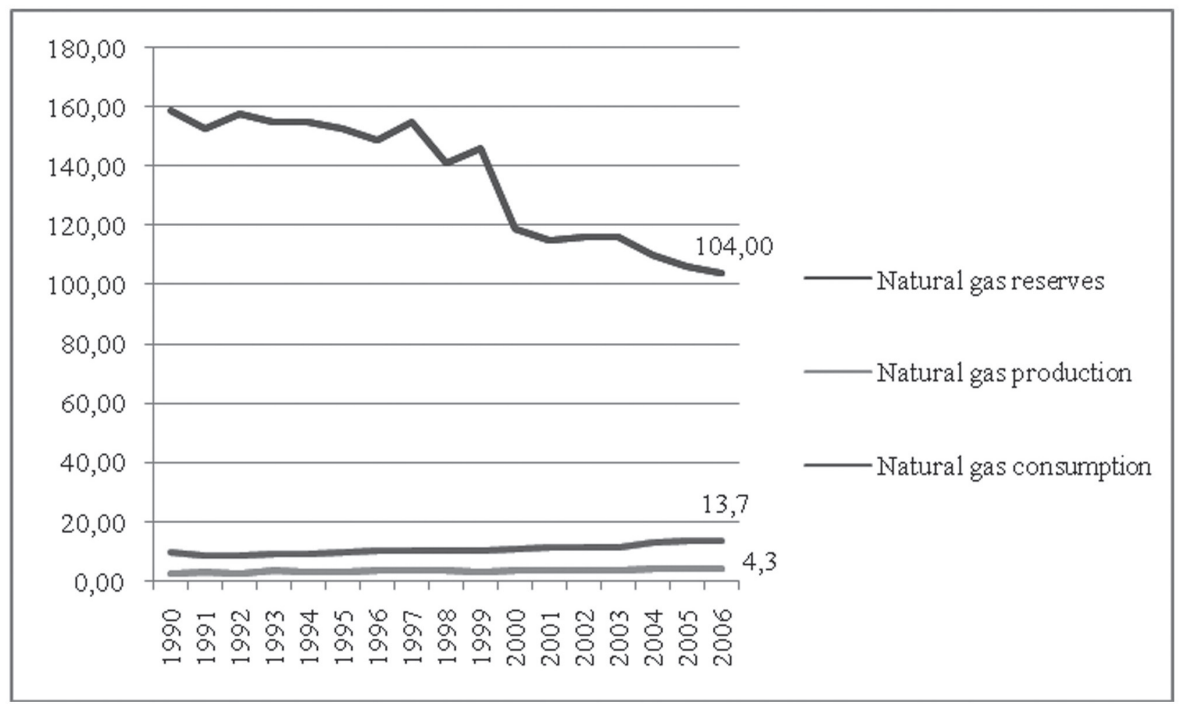

Figure 3. Natural Gas Reserves, Production, and Consumption in Poland ${ }^{17}$

Concerning the natural gas sector, Lithuania is in worse situation than Poland. In 2006 natural gas constituted $28.5 \%$ of total primary energy mix ${ }^{18}$. A total of $100 \%$ of consumed natural gas comes from Russia - natural gas imports are totally undiversified. Moreover, Lithuania's market is meaningless for Russia's exports - Lithuania imports only $1.4 \%$ of all Russia's natural gas exports. Gazprom could easily redirect this amount to other markets. Even joint

\footnotetext{
16 "Wintershall сделала предложение Польше" ["Wintershall made a proposal to Poland"], РБК daily, 200705 31, http://www.rbcdaily.ru/2007/05/31/tek/278103, 20070801 (in Russian).

${ }^{17}$ The BP Statistical Review of World Energy 2007 (note 15).

${ }^{18}$ Department of Statistics to the Government of the Republic of Lithuania, Energetikos statistika $2006 \mathrm{~m}$. [Energy statistics 2006], http://www.stat.gov.lt/lt/news/view/?id=1923, 20070620 (in Lithuanian).
} 
Lithuania's and Poland's import barely reaches $4.9 \%$ of entire Russia's natural gas exports (in 2006 Russia's natural gas export achieved $201.13 \mathrm{bcm})^{19}$.

\subsection{Importance of Lithuania and Poland to Russia's Natural Gas Exports to Western Europe}

Lithuania is insignificant natural gas transit country. Natural gas is supplied only to the Kaliningrad District through the territory of Lithuania $1.2 \mathrm{bcm}$ in 2006. Although transit increased by $66.9 \%$ in 2006 comparing to 2005 $(0,721 \mathrm{bcm}),{ }^{20}$ Lithuania cannot be described as a transit area in geo-energetic meaning (as a transporter), because amounts of transit do not reach consumption. In 2006 natural gas transit amounted $42.9 \%$ of consumption. On the other hand, in the case capacity of gas pipeline running through Lithuania to Kaliningrad was increased, Lithuania would become more important natural gas transit country. This perspective is a subject to at least two factors, first, the demand for natural gas in Kaliningrad and, second, the decision by Gazprom and Kremlin on future routes of natural gas supply to Kaliningrad. The demand for natural gas in Kaliningrad will reach 2 bcm in 2012. ${ }^{21}$ Additional quantity can be supplied whether capacity of gas pipeline through Lithuania (capacity is sufficient from Belarus to Lithuania) is increased or a new branch of Nord Stream gas pipeline along the bottom of the Baltic Sea is laid to Kaliningrad. The decision on the ways of further gasification of the Kaliningrad District is rather political one; therefore one should not expect economic solution. Accordingly an idea to build 1 billion USD worse branch of Nord Stream gas pipeline is not excluded..$^{22}$ It can be foreseen, that in the case Lithuania's and Russia's relations deteriorate, political support for the bypass route will increase and Lithuania's perspectives to become a transit country - will worsen.

\footnotetext{
19 "Russian Oil Exports Down 1\%, Gas Exports 3\% in 2006 - Ministry", RIA Novosti, 200702 01, http:// en.rian.ru/russia/20070201/60026020.html, 20070830.

${ }^{20} \mathrm{AB}$ "Lietuvos dujos", 2006 m. konsoliduotas metinis pranešimas [Consolidated annual report 2006], http://www.vpk.lt/uploads/metinis_pranesimas_2006.pdf, 20070801 (in Lithuanian).

${ }^{21}$ Рагузина Г., Калининград стал заложником амбиций энергетического и газового гигантов [Kaliningrad became a hostage of ambitions of energy and gas giants], http://www.bellona.ru/articles_ru/ chubais_tec, 20070623 (in Russian).

${ }^{22}$ Ibidem.
} 


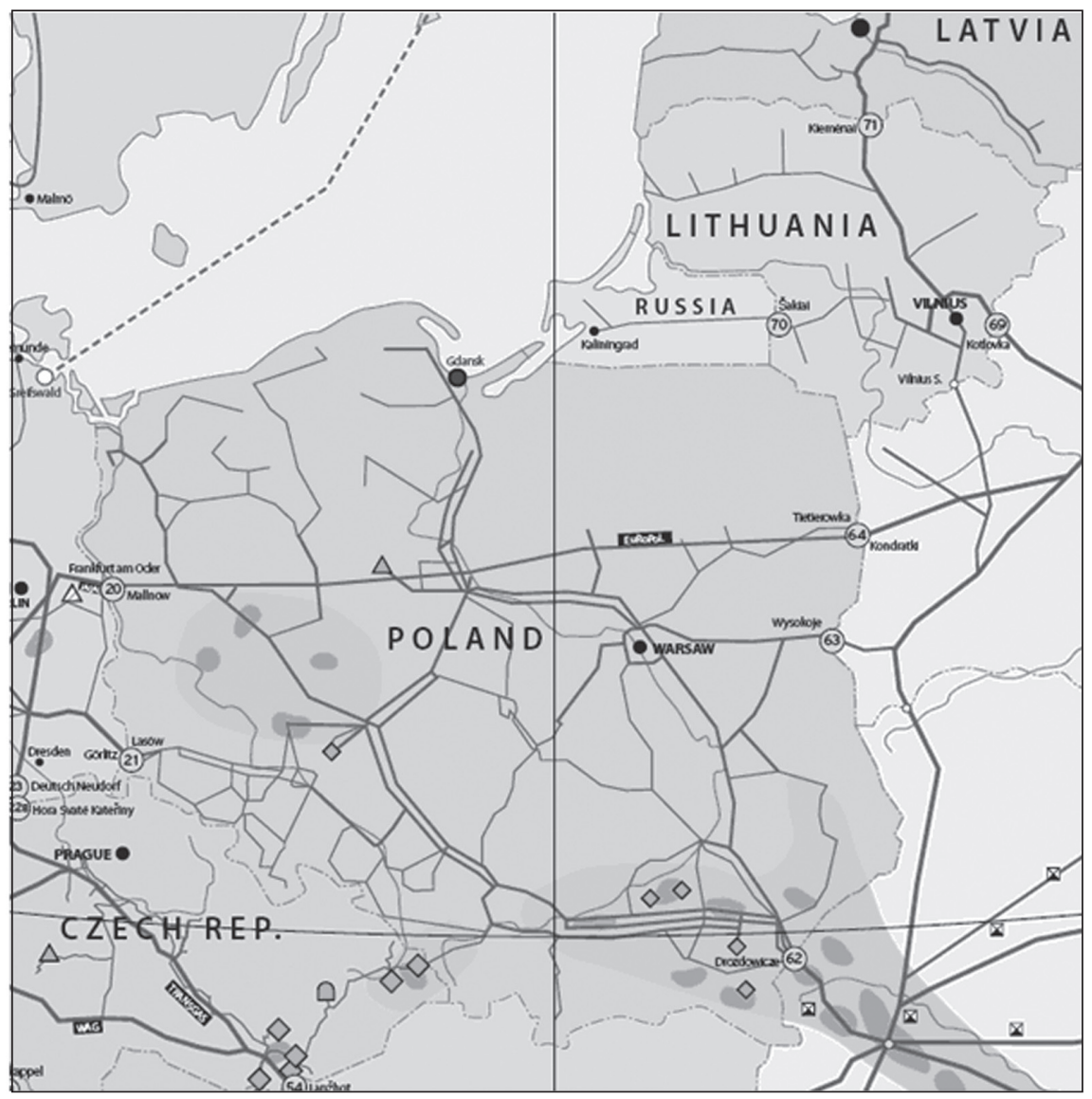

Map 1. Lithuania's and Poland's Gas Pipeline Networks ${ }^{23}$

Poland's role in Russia's natural gas exports to Western Europe - role of natural gas transit country - is significant. $25-26 \mathrm{bcm}$ of natural gas are transported to Germany through Poland by Yamal-Europe gas pipeline (projected capacity $-33 \mathrm{bcm}$ per year) annually ${ }^{24}$. Considering natural gas consumption in Poland (13.7 bcm in 2006), amounts of natural gas transit allows describing Poland as a country of natural gas transit. It means that Poland can influence a trade in natural gas between Russia and Western Europe. Moreover, Rus-

\footnotetext{
${ }^{23}$ Gas Transmission Europe, Operational Procedures at major cross-border interconnection points, http:// www.gie.eu.com/download/gridmap/GTE_OP_150.pdf, 20070716.

${ }^{24}$ Успенский А., "Поляки требуют от "Газпрома" отдать долг.

EuRoPol GAZ подсчитала разницу в тарифах” [The Polish claim for dept from Gazprom. EuroPol GAZ has counted difference in tariffs], РБК daily, 200701 17, http://pda.daily.rbc.ru/2007/01/17/ tek/263467.shtml, 20070511 (in Russian).
} 
sia does not have sufficient leverage to affect Poland's natural gas industry without harm to the interests of partners in Western Europe (Germany at the first place). How natural gas transit country may exploit - its position and role - was shown in the conflict between Russia and Belarus for natural gas prices in 2004 and 2006. The only guarantee Belarus had that Russia would not cut off supplies was transit through Belarus to Western Europe.

\subsection{Likely Geo-energetic Changes in the Natural Gas Sectors of Lithuania and Poland}

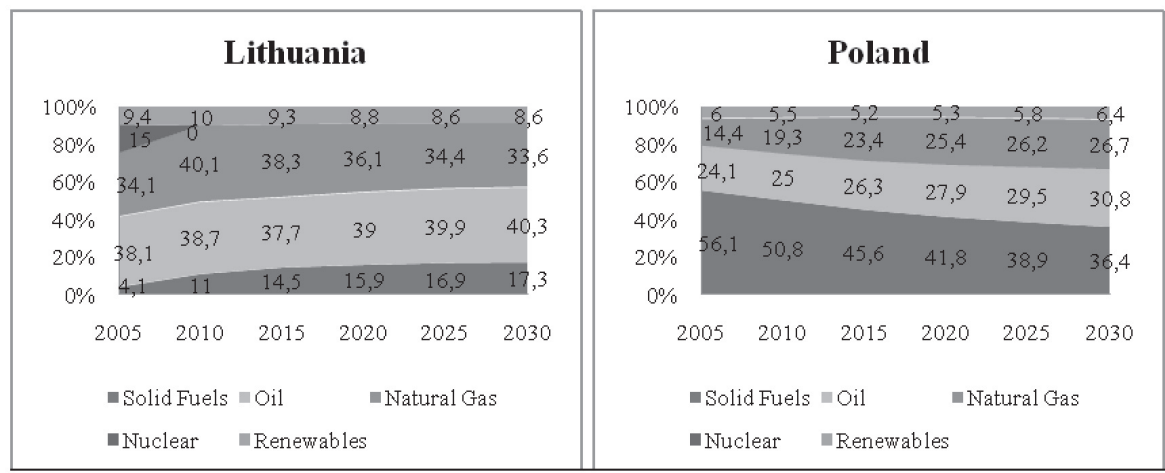

Figure 4. Gross Inland Consumption by Energy Resources in Lithuania and Poland ${ }^{25}$

Making an assumption that energy projects, which could change geoenergetic position of Lithuania and Poland, are not to be implemented - NPP, gas pipelines, liquefied natural gas (LNG) terminals - the balance of primary energy resources will change in both countries (see Figure 4). The major shift in Lithuania would be the end of nuclear energy (after the decommissioning of the Ignalina NPP) and the increase of natural gas consumption in short and medium term. However the share of natural gas should decrease and reach its former amount in the long term. Increase of Lithuania's natural gas consumption is insignificant - during the next 20 years it will grow only $1 \mathrm{bcm}$. This makes no impact on the natural gas market of the region. Lithuania will remain $100 \%$ dependent on Russia. Therefore, it can be concluded that there will be no fundamental shifts in the energy security of natural gas sector of Lithuania. Obviously, after the decommissioning of the Ignalina NPP more natural gas will be consumed for electricity production and vulnerability of the entire energy sector will increase as an outcome.

\footnotetext{
${ }^{25}$ European Commission, Directorate-General for Energy and Transport, European Energy and Transport Trends to 2030, 200301 30, http://ec.europa.eu/dgs/energy_transport/figures/trends_2030/1_pref_en.pdf, 20070412.
} 
Concerning energy security, forecasts of Poland's natural gas sector are worse than those of Lithuania. The share of natural gas in the balance of primary energy resources should increase from $14.4 \%$ in 2005 to $26.7 \%$ in 2030 (see Figure 5). Consumption will grow more than 2.5 times in this period; while production will shrink by one third (see Figure 3). It is forecasted that natural gas imports will face 3 times increase, Poland's dependency on imports will reach $92.6 \%$ in 2030 (in 2006 it was $72.2 \%$ ).

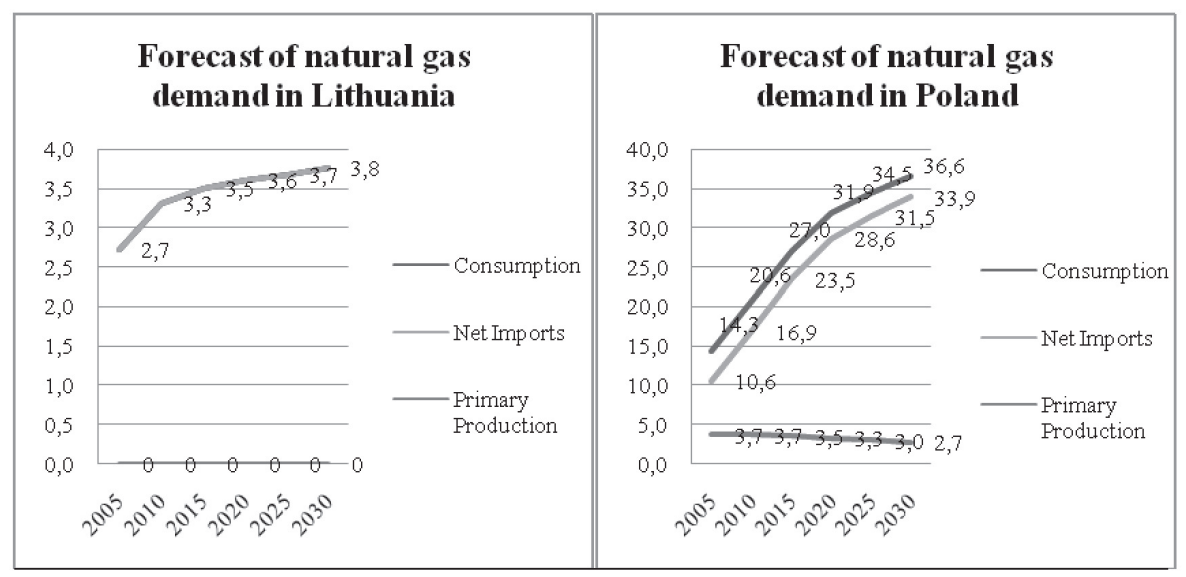

Figure 5. Forecasts of Natural Gas Consumption, Imports, and Production in Lithuania and Poland ${ }^{26}$

In the case a structure of natural gas imports remains the same, Poland will be forced to expand imports from Russia and satisfy increased demand. According to Russia's Energy Strategy till 2020, natural gas exports from Russia should increase by $30 \%$ in $2000-2010,4.5 \%-2010-2015,1.4 \%-2015-2020$ and finally arrive at 281 $\mathrm{bcm}$ in $2020^{27}$. Even making an overoptimistic assumption that natural gas exports will grow steadily by $4.5 \%$, it should reach $290 \mathrm{bcm}$ in 2030. Assuming that Poland will import additional natural gas from Russia, Poland's share in Russia's natural gas exports would make $9.1 \%$ in 2020 (Poland would import 25 bcm from Russia, while total imports would be $28.6 \mathrm{bcm}$ ) and $10.7 \%$ in 2030 . On the one hand, one tenth of whole natural gas exports looks like serious leverage at least in negotiations with Russia. On the other hand, it should be considered that increase of natural gas demand is forecasted in the whole EU as well as in Lithuania and Poland. Therefore, intense competition for Russia's natural gas is very feasible. It is highly

\footnotetext{
${ }^{26}$ Ibidem.

${ }^{27}$ Government of the Russian Federation, Энергетическая стратегия России на период до 2020 года [Russia 's Energy strategy to 2020], No. 1234-p, 200308 28. http://www.minprom.gov.ru/docs/strateg/1/ print, 20061125 (in Russian).
} 
doubtful that Poland will look more attractive in political and/or economic sense to Russia after 10 years than, for example, Germany or France. Consequently, energy security situation in Poland's natural gas sector will worsen in the future, if no improving measures are applied.

As it was stressed before, an increase of Russia's natural gas transit could partly neutralize the indicated negative trends. The only valid scenario for Lithuania to increase transit is the expansion of capacity of gas pipeline through Lithuania to the Kaliningrad District. This project is mentioned in the National Energy Strategy: "expansion and modernisation of the national gas transmission networks and ensuring the increase of natural gas transit through Lithuania, and that the conditions applied for transit are in line with the EU legal acts and their practical implementation." 28 The prognoses expected is that Kaliningrad will need 4.8 TWh of electricity in 2010 and 5.8 TWh in 2020 in the case of moderate scenario of economic development (3.6 TWh of electricity were consumed in Kaliningrad in 2005 $)^{29}$. Considering the closure of the Ignalina NPP and the fact that Lithuania will not be able to export electricity to Kaliningrad from 2010, Administration of the Kaliningrad District is implementing project of thermal power plant (TPP), which is going to consume $1.5 \mathrm{bcm}$ of natural gas working at full capacity. As it was mentioned, additional natural gas can be supplied whether through Lithuania or laying down a branch from Nord Stream gas pipeline. If Gazprom decides to increase supply through Lithuania, it will encourage Lithuania's transit function and improve the energy security in the natural gas sector (although $100 \%$ of imports would come from Russia). This would place Lithuania in a more favourable situation than that of Poland, however with the only exception that no other projects of natural gas infrastructure are implemented in the region.

\subsection{An Impact of Natural Gas Infrastructure Projects on Countries' Energy Security}

\subsubsection{Nord Stream Gas Pipeline}

Recently the Nord Stream gas pipeline (formerly known as North European Gas Pipeline) makes probably the largest firestorms among all natural gas projects. The new route has to connect natural gas field Yuzhno Russkoye and Germany through the Baltic Sea (from Vyborg in Gulf of Finland to Greifswald in Germany) ${ }^{30}$. It is not excluded to extend gas pipeline eventually to Netherlands and UK. In the beginning it was also planned that the branches of gas pipeline could reach

\footnotetext{
${ }^{28}$ Resolution on the Approval of the National Energy Strategy.

${ }^{29}$ Баланс электроэнергии Калининградской энергосистемы на период до 2020 года [Balance of electricity in the energy system of Kaliningrad to 2020], http://impera.ru/region/economics/electricity, 20070604 (in Russian).

${ }^{30}$ For example, see Nord Stream, Project Information Document: Offshore Pipeline Through the Baltic Sea, November 2006, http://www.nord-stream.com/uploads/media/PID_ENGLISH_01.pdf, 20070722.
} 
Finland and Sweden. Projected capacity of pipeline is $55 \mathrm{bcm}$ per year, the price more than 5 billion Euros. Project is included into the list of Trans-European Energy Network (TEN-E) Projects of European Interest ${ }^{31}$. Nord Stream is a part of NG1 connection between UK, Northern continental Europe, and Russia.

Nord Stream will supply natural gas from Russia to Western Europe bypassing Central and Eastern Europe because of political and economic reasons. The only way to avoid transit through this region is to build off-shore pipelines. It is declared that Nord Stream project will allow Russia's natural gas monopoly Gazprom to implement at least two tasks, first, to expand capacities of natural gas exports to Europe and, second, to diversify export routes and eventually decrease the role of transit countries (Ukraine, Belarus, and Poland). Western European countries-consumers that import Russian natural gas are also interested in bypassing transit countries. Direct interconnections without intermediaries presupposes stable supply, because, first, the supply is independent from relations between supplier and transporter (transit country) - experience of Belarus and Ukraine cases. Second, the supplier has less ways to diversify export and reorient supply - becomes more dependent on consumer. Third, the risk of decreased supply due to increased consumption in transit countries is reduced.

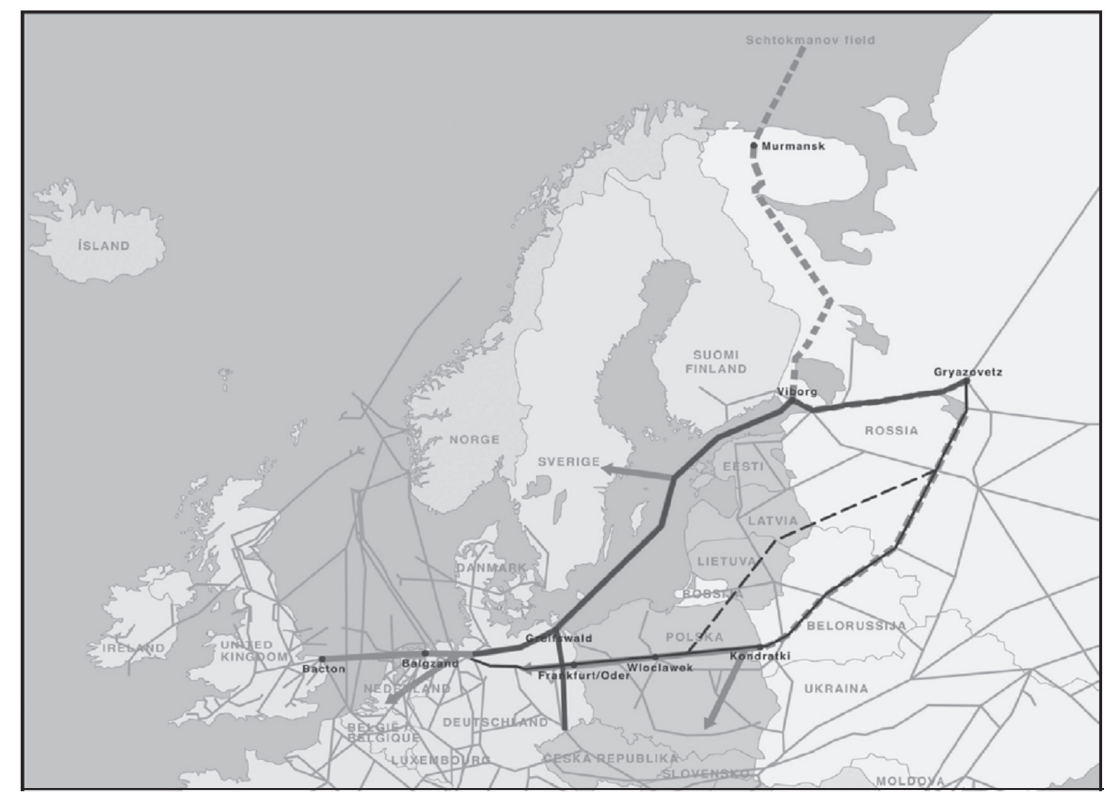

Map 2. Projected and Under Construction Gas Pipelines ${ }^{32}$

\footnotetext{
${ }^{31}$ Commission of the European Communities, Communication from The Commission to The Council and The European Parliament. Priority Interconnection Plan, COM(2006) 846 final, 200701 10, http://dete. parliament.bg/pub/ECD/COM_2006_846_EN_ACTE_f.pdf, 20070802.

${ }_{32}$ Морской газопровод через Балтийское море (проект) [Maritime pipeline through the Baltic Sea (project)], http://www.mnr.gov.ru/part/?act=more\&id=1291\&pid=781, 20070715 (in Russian).
} 
It is obvious that the Ukraine, Belarus, and Poland - Russia's natural gas transit countries - are least interested in new gas pipeline. Construction of bypass routes decreases their influence on Russia's exports and increases vulnerabilities. However, only Lithuania and Poland publicly challenge Nord Stream project. It is rational for Poland to oppose the project - Warsaw tries to convince Europe and Russia to build on-shore gas pipeline, primarily because it is cheaper. Polish experts are reasonably concerned that Russia will refuse to implement intergovernmental agreement that was signed between Poland and Russia in 1993 and according to which second line of Yamal-Europe gas pipeline through the territory of Poland should be build. Turning down of this project would bring financial losses to Poland and more important - will decrease Poland's role in the flow of natural gas to EU.

Nord Stream will threaten Lithuania's energy security only if (environmental and military threats are not assessed in this article) the branch from gas pipeline is laid to the Kaliningrad District and exclave becomes independent from the transit through Lithuania. Chances that this is going to happen are low; on the other hand, it is always worthless to work at predicting Moscow's moves towards "selfish neighbours".

Concerning the construction of Nord Stream, Lithuania could be more flexible than Poland, because interests of both countries do not match. Poland seeks to build the second line of Yamal-Europe gas pipeline (also known as Yamal II) and to increase transit. Transit will not increase through Lithuania in any case - whether Nord Stream or Yamal II is built. Therefore for Lithuania's energy security there is no major difference, which of the projects will be implemented (if a branch to Kaliningrad from Nord Stream is not built).

\subsubsection{Yamal II and Amber}

The Yamal II project, even in the EU Priority Interconnection Plan, is called a competitor of Nord Stream, which is supported by Poland and Baltic States $^{33}$. Lithuania's support to Yamal II could be based on energy security interests only if there was proposed a branch from gas pipeline to Lithuania, which would diversify routes of natural gas imports (while supplier remains the same) and reduce the risk of supply interruptions. Unfortunately, there are no plans to built branches to Lithuania - Yamal II would bypass country as Nord Stream.

According to the project, the Yamal II should be laid parallel to the first line of Yamal-Europe gas pipeline. Length of route is $700 \mathrm{~km}$, capacity -43 $\mathrm{bcm}$, price -1.5 billion Euros ${ }^{34}$. Transit through second line (bearing in mind, that Poland will consume natural gas, supplied through the first line in the long term) would guarantee Poland the role of significant transporter and revenues

\footnotetext{
${ }^{33}$ Priority Interconnection Plan (note 31).

${ }^{34}$ Ibidem.
} 
from transit. Poland would remain one of the factors of energy security of Western Europe and, eventually, would gain additional political influence. The Polish gas company PGNiG has submitted a proposal for a feasibility study; however the European Commission agreed only under condition that the relevant Member States and companies should be involved. ${ }^{35}$ No other companies had joined PGNiG, and the latter had to resign from the study. The reason of PGNiG singleness was lack of Russian Gazprom and German E.ON interest to implement a project competing with the Nord Stream gas pipeline project, which is planned to transport natural gas to the same market.

Yamal II can be constructed probably after, first, the Nord Stream operates in full capacity; second, the demand for natural gas grows in Western Europe faster than expected; third, the production of natural gas increases in Russia faster than expected; fourth, Western European countries still have interest to increase imports from Russia; fifth, relations between Russia and Belarus as well as Russia and Poland are satisfactory enough for Moscow to treat these countries as reliable partners for energy cooperation. It is difficult to forecast when (if ever) all these conditions will be satisfied. Even it happens Yamal II will be discussed not earlier than sometime between 2015-2020.

Although Yamal II is considered to be an alternative to Nord Stream in EU, Amber gas pipeline project is seen as such an alternative in Lithuania. For example, in the National Energy Strategy it is said that one of the factors influencing a stable functioning of the energy sector in Lithuania is "the construction of a new gas pipeline to Europe under the Baltic Sea bypassing the territory of the Baltic States." ${ }^{36}$ On the other hand, Amber is not even listed in the EU Priority Interconnection Plan, it is marked only as a "Project of Common Interest." ${ }^{37}$ Amber route would have to run parallel to Yamal gas pipeline, so it can be called an alternative to Yamal II.

Amber could strengthen energy security of Lithuania. First, Lithuania could integrate into EU gas pipeline networks and become a part of a single European internal market in natural gas. Second, Amber allows diversifying routes of natural gas imports from Russia and reduces risks of supply interruptions. Third, the new pipeline would make natural gas exports from Russia dependent on Lithuania - stable supply to EU would be directly related to stable supply through Lithuania. This factor could diminish Russia's capabilities to manipulate amounts and prices of natural gas. Fourth, Lithuania's role in supplying the Kaliningrad District would increase. Fifth, Lithuania could receive revenues from transit.

Although the Amber gas pipeline looks attractive, the project has less than minimal chances to be implemented. It cannot compete with Yamal II - the

\footnotetext{
${ }^{35}$ Ibidem.

${ }^{36}$ Resolution on the Approval of the National Energy Strategy.

${ }^{37}$ The European Parliament and The Council Of The European Union, Decision of The European Parliament and of The Council. Laying Down Guidelines for Trans-European Energy Networks and Repealing Decision 96/391/EC and Decision No 1229/2003/EC, No 1364/2006/EC, 200609 06, http://eur-lex. europa.eu/LexUriServ/site/en/oj/2006/1_262/1_26220060922en00010023.pdf, 20070115.
} 
Polish project does not require buying out land or getting permissions for constructions. In the case of Gazprom and the German counterparts if they decide to resign from a Nord Stream, it is very unfeasible, that they would choose to start negotiations with the Baltic Countries on new project, become dependent on them and pay transit tariffs only in purpose to bypass Belarus. Amber project can be implemented after, first, Nord Stream and Yamal II operates at full capacity; second, these pipelines do not satisfy EU's demand for natural gas; third, Russia can increase production of natural gas; fourth, Russia agrees to increase exports to Western Europe and does not seek to diversify it; fifth, EU countries agree to boost imports from Russia; sixth, Russia does not refuse to make the Baltic States transit countries of its natural gas exports and to become dependent on them. Making an assumption that there are no impossibilities, all mentioned conditions could be fulfilled beyond the limits of meaningful forecast - not earlier than 2030. Therefore it should be not considered as feasible project, which can strengthen the hope for energy security.

\subsubsection{A Gas Pipeline Connecting Lithuania and Poland}

One of the weaknesses of Lithuania's energy sector is an absence of interconnections with Western European energy systems. ${ }^{38}$ As the opportunities are indicated the following projects: first, the construction of LNG terminal in the Baltic region (not necessarily in the Baltic States). LNG terminal is also called Lithuania's interest in the Baltic region - "development of the natural gas supply system and system interconnections with EU gas networks providing for consideration, in co-operation with Latvian, Polish and Estonian experts, of the expediency of construction of a regional liquefied natural gas import terminal." ${ }^{\prime 39}$ Second, the interconnection of gas pipeline networks of Lithuania and Poland - "with the construction of gas pipeline to Eastern Europe from alternative sources (the Caspian Sea or Norway) and interconnection of gas pipeline networks of Lithuania and Poland, Lithuania acquire possibilities of alternative gas supply." 40

The gas pipeline that is mentioned in National Energy Strategy could connect gas pipeline network of Lithuania with, first, the gas pipelines transporting Russia's natural gas through Poland, second, the projected LNG terminal in Poland, third, the gas pipelines transporting natural gas from alternative to Russia sources - Norway or the Caspian Sea Basin. All of the mentioned projects are whether hardly implemented or too small to be joint by Lithuania. The only project that plans to transport Russian gas is Yamal II, but, firstly, it is not to be constructed in the medium term and, second, connection to Lithuania is not planned. Lithuania could join LNG terminal project in Poland, if, first, it

\footnotetext{
${ }_{38}^{38}$ Resolution on the Approval of the National Energy Strategy.

${ }^{39}$ Ibidem.

${ }^{40}$ Ibidem.
} 
was constructed, second, its capacity would allow connecting other consumers, third, the terminal was close to Lithuanian border - otherwise construction of interconnection becomes economically unfeasible. The same conditions can be applied assessing Lithuania's chances to connect to gas pipelines from Norway and/or the Caspian Sea: first, they should reach Poland, second, there should be enough gas for Lithuania, third, they should be not far away from Lithuanian border with Poland. Therefore decision on construction of pipeline, which can strengthen strategic energy partnership between the countries, can be made after choosing among projects to connect with.

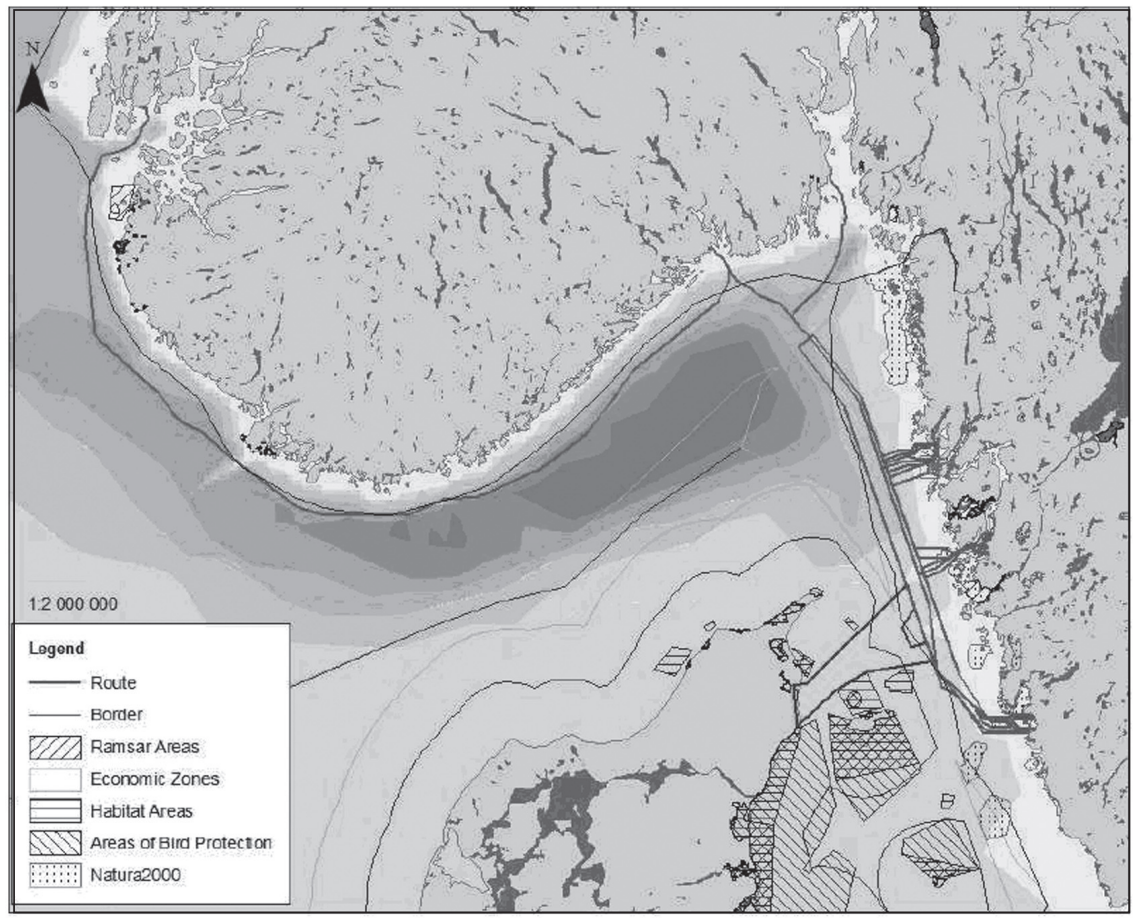

Map 3. Skanled Gas Pipeline ${ }^{41}$

Poland links its diversification of natural gas supply tasks with natural gas imports from Norway. Already in 2001 Poland agreed with Denmark and Norway on Baltic Pipe gas pipeline project - new route for transportation of Norway's natural gas through Denmark to Poland. Unfortunately, as an outcome of Russia's pressure, Denmark's vague position, and Poland's internal political problems project had not been started. In the beginning of 2007 new

\footnotetext{
${ }^{41}$ Gassco and DNV, Information Concerning the Planning of the Skanled Gas Pipeline, June 2007, http://www.energinet.dk/NR/rdonlyres/E7D26121-FE5C-46C9-9DCB-7BE95E65CD38/0/ TheSkanledgaspipelineprojectsummaryver_02_250607.pdf, 20070905.
} 
impulse for Poland's attempts to diversify imports was contract between PGNiG and ExxonMobil on purchase of 15\% of shares in two fields on Norway's continental shelf - Skarv and Snadd. ${ }^{42}$ Production should start in 2011 and run for $20-25$ years. $15 \%$ of shares would guarantee about $0.2-0.6 \mathrm{bcm}$ of natural gas per year..$^{43}$ Such an amount of gas allows for the diversifying of imports only 'politically.' because there would be no significant impact on the structure of imports. Besides, the problem of transportation from Norway remains.

Because of lack of transportation capacity Poland seeks to connect to Scandinavian natural gas network. In 2007 PGNiG joined the consortium led by Norwegian Gassco, which builds Skanled gas pipeline from Karst in Norway to Sweden and Denmark (see Map 3). PGNiG purchased $15 \%$ of shares in pipeline. Constructions of Skanled begin in 2009 and pipeline is planned to be operative in 2011. Its capacity will be $7 \mathrm{bcm}$ per year. ${ }^{44}$ Considering production limit of Karst (9 bcm per year), it is highly feasible that capacity of Skanled will be increased.

In 2007 PGNiG also made a deal with Danish Energinet.dk on feasibility study on Baltic Pipe gas pipeline from Denmark to Poland under the Baltic Sea. Baltic Pipe should connect Skanled with Poland, which will have an opportunity to import natural gas from Norway. Companies agreed that PGNiG will finance the project and is an owner of it at the initial phase ${ }^{45}$. PGNiG representatives stress, that Skanled and Baltic Pipe allow Poland improving its energy security, eliminating supply interruptions, decreasing dependency on single supplier, and increasing natural gas imports. ${ }^{46} \mathrm{It}$ is interesting, that companies are considering an option to build reversible gas pipeline. ${ }^{47}$ It means that Poland and Denmark would have a possibility to transport natural gas from Norway through Denmark to Poland as well as from Russia through Poland to Denmark (Poland could hold on to the transit function).

Poland's plans to import natural gas from Norway will not essentially solve the problem of increased dependency on Russia. PGNiG share in Skarv and Snadd fields cannot assure adequate quantity of natural gas. Moreover, Poland's share in Skanled gas pipeline could allow transporting no more than $1-1.5 \mathrm{bcm}$ per year. Therefore it is not clear, where Poland is going to get additional natural gas for Baltic Pipe.

\footnotetext{
${ }^{42}$ PGNiG to Acquire Stake in Norwegian Shelf Licences, http://www.rigzone.com/news/article.asp?a $\mathrm{id}=41995,20070906$.

${ }^{43}$ PGNiG Will Acquire Hydrocarbon Reserves on the Norwegian Shelf, http://reakkt.wordpress. com/2007/03/01/pgnig-will-acquire-hydrocarbon-reserves-on-the-norwegian-shelf/, 20070906.

${ }^{44}$ Herron J., ““'Expansion Likely on Norway-Denmark Gas Pipeline”, Dow Jones Newswires, 20070907, http://www.downstreamtoday.com/News/ArticlePrint.aspx?aid=5854, 20070906.

${ }^{45}$ Watson C., "Denmark and Poland Considering Gas Pipeline", Energy Business Review Online. http://www.energy-business-review.com/article_news.asp?guid=464FFA34-5CEC-4DFA-A80C5D0DC8312455, 20070906.

${ }^{46}$ Polish Oil and Gas Company Joins Skanled Consortium, http://www.en.pgnig.pl/316_2414.htm, 2007 0906.

47 "PGNiG and Energinet.dk reached agreement on Baltic Pipe“, Scandinavian Oil-Gas Magazine, http:// www.scandoil.com/moxie-bm2/news/contracts_world/pgnig-and-energinetdk-rea.shtml, 20070906.
} 


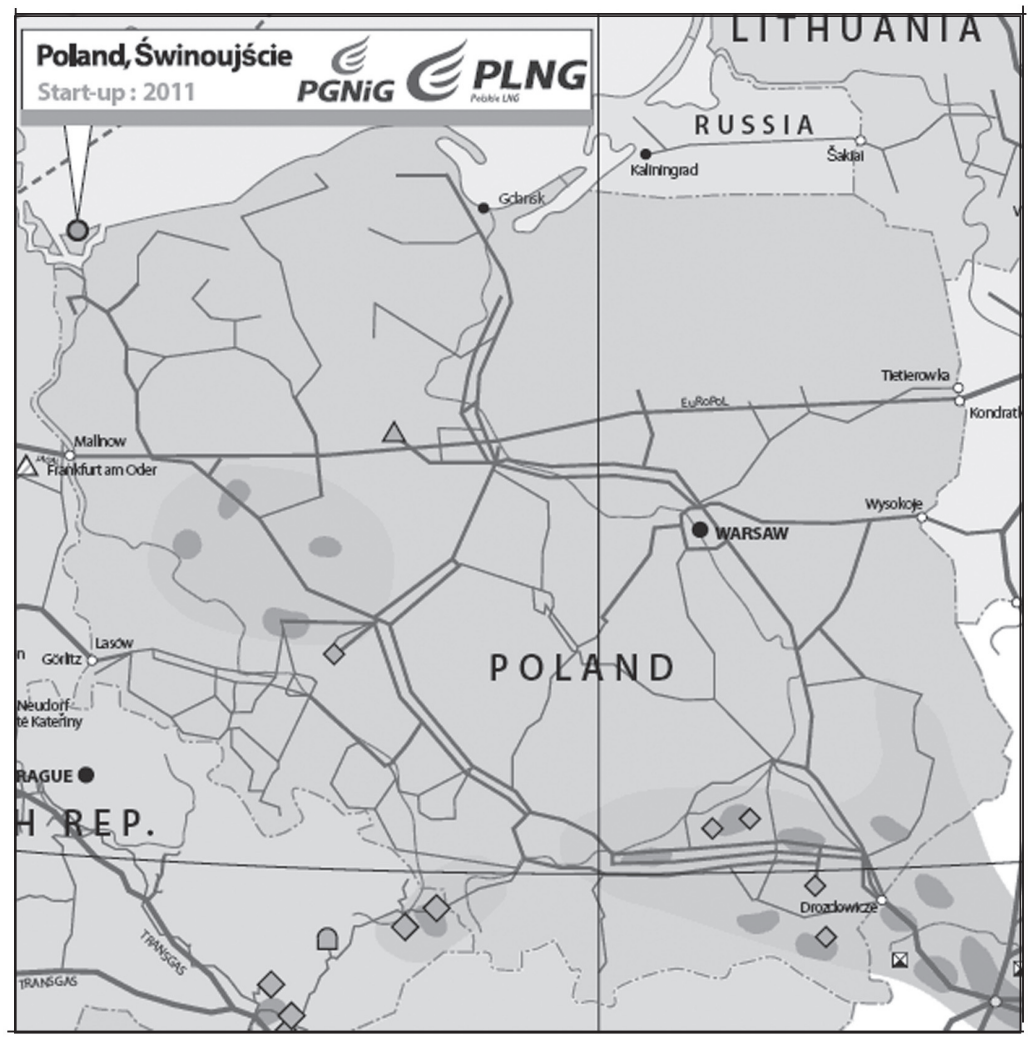

Map 4. Projected LNG Terminal in Poland ${ }^{48}$

Another direction of improvement in regards to energy security is the project of the LNG terminal in Poland. LNG terminal in Gdansk is listed in Priority Interconnection Plan next to other NG4 projects. In 2005-2006 it was assumed that LNG terminal with capacity of $3-5 \mathrm{bcm}$ would cost 500 million Euros and be operative in 2010 - the construction had to begin in $2007 .{ }^{49}$ However, in 2006 PGNiG announced tender for feasibility study of LNG terminal. Two options were assessed - Gdansk and Swinoujscie (see Map 4), which is $300 \mathrm{~km}$ to the West from Gdansk. PGNiG has chosen second option, because, first, route for LNG tankers is shorter; second, the North Eastern regions of Poland have less developed network of gas pipelines; third, the power plants in the region could shift from coal to natural gas ${ }^{50}$; fourth,

\footnotetext{
${ }^{48}$ LNG Map. Information by Entry Point, http://www.gie.eu.com/download/gridmap/GLE_LNG_207.pdf, 20070810.

${ }^{49}$ Signing of a Letter of Intent Regarding the Construction of the Maritime Gas Terminal in the Port of Gdansk, http://www.portgdansk.pl/events/a-letter-of-intent-regarding-the-construction-of-the-lng-terminal, 20070810.

${ }^{50}$ Jeziorski M., “““Alternative Access”, The Warsaw Voice, 200601 18, http://www.warsawvoice. pl/view/10305, 20070810.
} 
the infrastructure of port is more suitable. ${ }^{51}$ It is obvious that possibilities of transportation of re-gasified LNG to Lithuania were not among the assessed criteria.

Capacity of projected terminal is $2.5 \mathrm{bcm}$ per year with option to increase it till 5-7.5 bcm. ${ }^{52}$ This amount would allow Poland diversifying imports and supplying industrial plants of North Western regions. Lithuania's connection to the terminal, even without economic feasibility study, is hardly feasible firstly because of the price of gas pipeline to Lithuania (doubtfully Poland would agree to share the costs in support of the "strategic partnership"). Moreover, if Lithuanian companies are ready to invest their money for the latter gas pipeline, it will be more rational to build alike terminal in Lithuania.

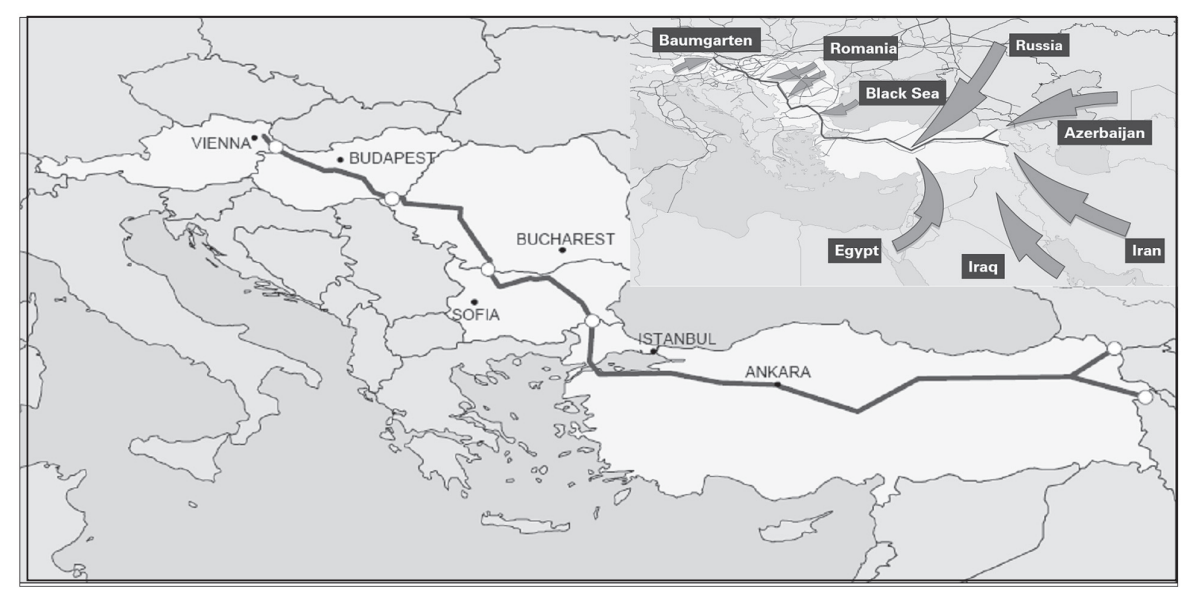

\section{Map 5. Nabucco Gas Pipeline ${ }^{53}$}

Third mentioned option for Lithuania is connection to gas pipelines that transport natural gas from the Caspian Sea. For the moment there is only one project of natural gas supply from the Caspian Sea to Europe - Nabucco. ${ }^{54}$ The gas pipeline has to connect the Caspian Sea and Middle East suppliers through Turkey, Bulgaria, Romania, Hungary and Austria with Western European

\footnotetext{
${ }^{51}$ Management Board of PGNiG selects the Location for LNG Terminal on the Polish Coast, http://www. en.pgnig.pl/cp/news/478_2208.htm, 20070810.

${ }^{52}$ Poland Moves in New Directions Regarding Liquid Natural Gas Import, http://www.ilf.de/index. php?id=63\&L=1\&tx_ttnews\%5Btt_news\%5D=131\&tx_ttnews\%5BbackPid\%5D=18\&cHash=b675b139 48, 20070810.

${ }^{53}$ Nabucco Gas Pipeline International GmbH, Nabucco Gas Pipeline Project. Gas Bridge Between Caspian Region/Middle East/Egypt and Europe, February 2007, http://www.nabucco-pipeline.com/cms/upload/Partner_Logos/Nabucco_presentation_web_Feb_2007.pdf, 20070705.

${ }^{54}$ In 2002 an idea of Nabucco gas pipeline was drafted by Austrian and Turkish companies OMV and BOTAS. Later on Bulgarian Bulgargaz, Romanian Transgaz and Hungarian MOL joined them. These five companies agreed to implement feasibility study in 2002. Feasibility study concluded, that project is technically and economically feasible. In 2005 joint company for construction of pipeline was established. Construction has to begin in 2009 and pipeline has to be operative already in 2012 .
} 
natural gas market. The length of the projected route will be $3300 \mathrm{~km}$, capacity $31 \mathrm{bcm}$ per year, price -5 billion Euros..$^{55}$ The starting points of gas pipeline are planned at the border of Turkey and Georgia as well as Turkey and Iran, ending - Baumgarten Hub in Austria. In the project's reasoning there are four main strategic goals declared: first, "opening a new gas supply corridor for Europe and for the countries involved in the project, for very cost-effective gas sources"; second, "raise the transit role of the participating countries along the route"; third, "contribution to the security of supply for all partner countries, and also for Europe as a whole"; fourth, "strengthening the role of the gas pipeline grids of all Nabucco partners in connection with the European gas network." ${ }^{156} \mathrm{Nabucco}$ has to connect giant natural gas reserves with insatiable European market of natural gas through the Black Sea region and strengthen the role of Central Europe as a transit area.

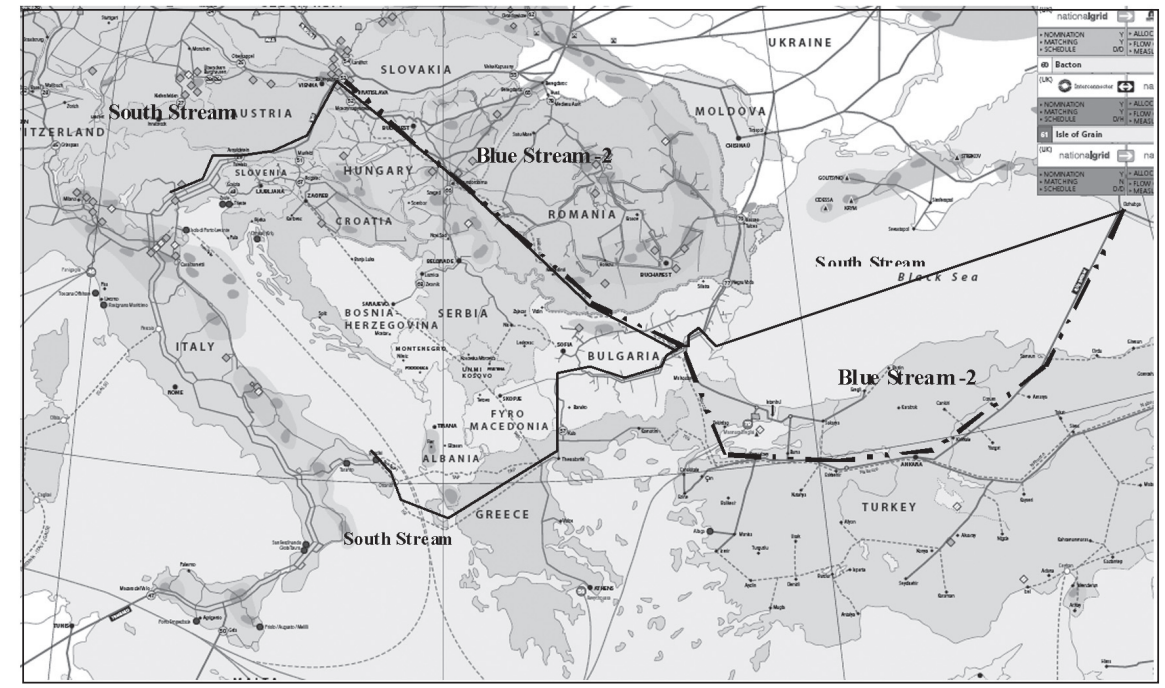

Map 6. Competitors of Nabucco Gas Pipeline ${ }^{57}$

However, Nabucco lacks the main part of the chain - supply. All five companies that attend the project represent transit and consumer countries there are no companies that produce sufficient amount of natural gas in the Caspian Sea or Middle East. This is a major challenge to the pipeline, to which Poland wishes to connect. Second challenge is alternative projects in the region, which are initiated and pushed forward by Russia - exporter with guaranteed supplies. Alternative projects are: Blue Stream 2 - extension of Blue Stream gas

\footnotetext{
${ }^{55}$ Nabucco Project Description, http://www.nabucco-pipeline.com/project/project-description-pipelineroute/index.html, 20070705.

${ }^{56}$ Nabucco Project. Mission Statement/Strategic Goals, http://www.nabucco-pipeline.com/company/mission-statement-strategic-goals/index.html, 20070705.

${ }^{57}$ Operational Procedures at major cross-border interconnection points.
} 
pipeline, which runs from Russia to Turkey under the Black Sea, to Central Europe; South Stream (backed by Italy's ENI and Russia's Gazprom) - gas pipeline project from Russia to Bulgaria under the Black Sea and eventually to Italy (see Map 6). Although Nabucco has strong political backing in Europe, its positions are weaker vis-a-vis competitors, because Russia, first, offers natural gas in one package with gas pipelines, second, has support of potential consumers in Western Europe, third, is able to attract key transit countries (Bulgaria in the case of South Stream or Hungary in the case of Blue Stream 2).

Even some supplier(s), except Russia, guarantees to load completely Nabucco in 2020 (30 bcm per year), there are no assurances that it will ever reach Poland. First, Poland is not a partner in the project. Second, part of transported gas will remain in the transit countries. Therefore it is not clear how much of natural gas will be available for sale in Baumgarten. Third, the interconnections between Poland and Czech Republic (which has connections to Baumgarten) are insufficient. In the case Nabucco is built and there is available gas for Poland (and its price is reasonable to build a gas pipeline), there doubtfully will be any left for Lithuania. Taking into account that Baumgarten natural gas storages have connection with Western European natural gas network, any alternative transportation further from Baumgarten through newly built infrastructure would be uncompetitive. Therefore, it may be concluded that Lithuania's hopes to import natural gas from the Caspian Sea are unreasoned. In the case Lithuania has a chance to become a transit country of natural gas to Western Europe, Nabucco will be even harmful to its energy security, because it would strengthen the role of South Eastern Europe vis-a-vis Central and Eastern Europe in the trade of energy resources.

\section{Relations between Lithuania and Poland in the Electricity Sector}

\subsection{Differences in the Electricity Industries of Lithuania and Poland}

Electricity industries in Lithuania and Poland differ in fuel inputs for electricity generation. More than $70 \%$ of electricity are produced in the Ignalina NPP in Lithuania, while coal dominates electricity production in Poland - more than $90 \%$. Second difference - from 2001 Poland is a member of the Union for the Coordination of Transmission of Electricity (UCTE). UCTE unites almost all electricity transmission grids in Western and Central Europe. Poland has also connections with Ukraine and Belarus - members of UPS/IPS system, which unites former Soviet Union. Lithuania has connections only with UPS/IPS. The only Lithuania's connection with Poland is through Belarus, which has two connectors with Poland.

The main similarity between Lithuania and Poland is that both countries 
are exporters of electricity (see Table 3). However they cannot be described as competitors, because countries sell electricity to different markets and are not interconnected. The biggest share of Lithuania's export was directed to Latvia (0.7 TWh), Belarus (0.63 TWh) and Russia (0.46 TWh), import - from Russia $(1.39 \mathrm{TWh})^{58}$. Poland is sixth largest exporter of electricity in EU ${ }^{59}$. In 2005 Poland exported electricity to Czech Republic (11.1 TWh), Slovakia (2.8 TWh), Sweden (1.2 TWh) and Germany (1 TWh), imported - from Germany (2.3 TWh), Ukraine (1 TWh), Belarus (0.9 TWh) and Sweden $(0.8 \mathrm{TWh})^{60}$.

Table 3 Balances of Electricity Sectors in Lithuania and Poland in $\mathbf{T W h}^{61}$

\begin{tabular}{|c|c|c|c|c|c|c|c|c|c|c|}
\hline & \multicolumn{5}{|c|}{ Lithuania } & \multicolumn{5}{|c|}{ Poland } \\
\hline & 2004 & 2005 & 2006 & $\begin{array}{c}2005 / \\
2004 \\
\% .\end{array}$ & $\begin{array}{c}2006 / \\
2005 \\
\%\end{array}$ & 2004 & 2005 & 2006 & $\begin{array}{c}2005 / \\
2004 \\
\%\end{array}$ & $\begin{array}{c}2006 / \\
2005 \\
\%\end{array}$ \\
\hline $\begin{array}{l}\text { Total net } \\
\text { produc- } \\
\text { tion }\end{array}$ & 17.7 & 13.6 & 11.0 & -23.2 & -19.1 & 140.8 & 143.6 & 147.3 & 2.0 & 2.6 \\
\hline $\begin{array}{l}\text { Conven- } \\
\text { tional } \\
\text { thermal }\end{array}$ & 2.7 & 3.0 & 2.5 & 11.1 & -16.7 & 137.0 & 139.7 & 144.0 & 2.0 & 3.1 \\
\hline Nuclear & 13.9 & 9.5 & 7.9 & -31.7 & -16.8 & & & & & \\
\hline $\begin{array}{l}\text { Hydro } \\
\text { and other }\end{array}$ & 1.1 & 1.1 & 0.6 & & -45.5 & 3.8 & 3.9 & 3.3 & 2.6 & -15.4 \\
\hline Imports & 4.3 & 5.6 & 5.8 & 30.2 & 3.6 & 5.3 & 5.0 & 4.8 & -5.7 & -4.0 \\
\hline Exports & 11.5 & 8.6 & 6.2 & -25.2 & -27.9 & 14.6 & 16.2 & 15.8 & 11.0 & -2.5 \\
\hline $\begin{array}{l}\text { Energy } \\
\text { absorbed } \\
\text { by pump- } \\
\text { ing }\end{array}$ & 0.7 & 0.5 & 0.6 & -28.6 & 20.0 & 2.3 & 2.2 & 1.6 & -4.3 & -27.3 \\
\hline $\begin{array}{l}\text { Energy } \\
\text { supplied }\end{array}$ & 9.8 & 10.1 & 10.0 & 3.1 & -1.0 & 129.2 & 130.2 & 134.7 & 0.8 & 3.5 \\
\hline \multicolumn{11}{|c|}{ Contribution of the sources to the production in \% } \\
\hline $\begin{array}{l}\text { Conven- } \\
\text { tional } \\
\text { thermal }\end{array}$ & 15.3 & 22.1 & 22.7 & & & 97.3 & 97.3 & 97.8 & & \\
\hline Nuclear & 78.5 & 69.9 & 71.8 & & & & & & & \\
\hline $\begin{array}{l}\text { Hydro } \\
\text { and other }\end{array}$ & 6.2 & 8.1 & 5.5 & & & 2.7 & 2.7 & 2.2 & & \\
\hline
\end{tabular}

\footnotetext{
${ }^{58}$ Ministry of Economy of the Republic of Lithuania, Tiekimo saugumas Lietuvos elektros energijos rinkoje. Monitoringo ataskaita [Security of supply in the electricity market of Lithuania. Report of monitoring], 2007, http://www.ena.lt/pdfai/Monitoringas_2007.pdf, 20070906 (in Lithuanian).

${ }^{59}$ Panorama of the European Union. Gas and Electricity Market Statistics. 2006 Edition, Luxembourg: Office for Official Publications of the European Communities, 2006, http://ep.eurostat.ec.europa.eu/ cache/ITY_OFFPUB/KS-76-06-289/EN/KS-76-06-289-EN.pdf, 20070822.

${ }^{60}$ UCTE, Statistical Yearbook 2005, http://www.ucte.org/_library/statsyearbook/Statistical_Yearbook_ 2005.pdf, 20070903.

${ }^{61}$ Bassan M., "Electricity Statistics - Provisional data for 2006". Eurostat Data in Focus, 4/2007. http:// epp.eurostat.ec.europa.eu/cache/ITY_OFFPUB/KS-QA-07-004/EN/KS-QA-07-004-EN.PDF, 20070802.
} 
Poland is biggest producer and consumer of electricity in all of Central Europe. Although it is estimated that the consumption of electricity will increase and old coal-fired power plants should be closed or renovated, Poland will have sufficient power reserve to remain exporter of electricity. ${ }^{62}$ Lithuania is exporter of electricity only till the end of 2009 - the decommissioning of the Ignalina NPP. In the National Energy Strategy it is foreseen that "after the decommissioning of Unit 2 of the Ignalina NPP at the end of 2009, the current generating capacities, including small capacity CHP plants that are planned to be constructed, will be sufficient to meet the national demand until 2013. ${ }^{\prime 63}$ However Lithuania may face the need to import electricity even earlier, because the price of electricity that is produced in the Lithuanian Power Plant may not be competitive. Lithuania will convert from the exporter to the importer. Although the options to import electricity from other UPS/IPS countries are considered, the most probable future supplier of electricity is Russia - eventually this would increase dependency of Lithuania's energy sector on Russia.

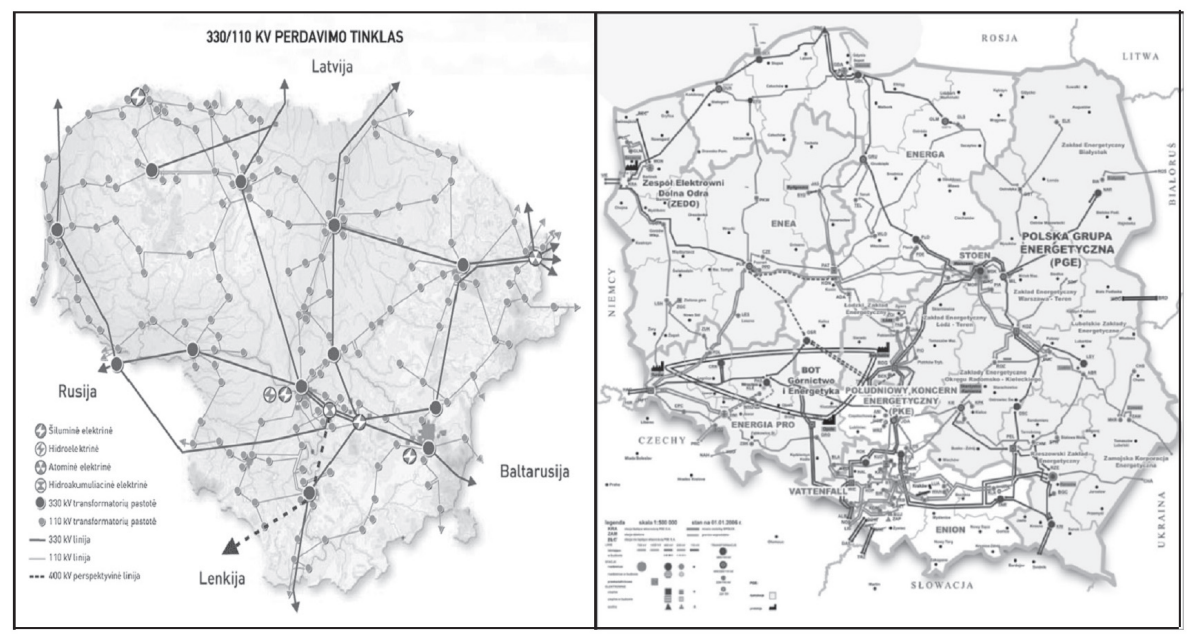

Map 7. Electricity Transmission Network in Lithuania and Poland ${ }^{64}$

\footnotetext{
${ }^{62}$ For example, see Deksnys R., Atominès elektrinès konkurencingumo Baltijos, Skandinavijos, Vakaru Europos šaliu ir Rusijos elektros energijos rinkose analizè (galutine ataskaita) [Analysis of competitiveness of nuclear power plant in the Baltic, Scandinavian, Western European and Russian markets (final report)], Department of Electric Power Systems at Faculty of Electrical engineering and control systems in Kaunas University of Technology, 20051201 (in Lithuanian).

${ }^{63}$ Resolution on the Approval of the National Energy Strategy.

${ }^{64} 330 / 110 \mathrm{kV}$ perdavimo tinklas [330/110kV transmission network], http://www.lietuvosenergija.lt/lt/main/ system/network, 20070815 (in Lithuanian). Polish Energy Group, http://www.pse.pl/galeria/pge_01.jpg, 20070815.
} 


\subsection{Joint Projects between Lithuania and Poland in the Electricity Sector}

In purpose to reduce the threats to the energy security in the electricity sector, the National Energy Strategy indicates the following tasks (beside to the construction of new thermal power plants, renovation programmes and others): first, the interconnection of Baltic electricity transmission networks with the networks of Poland and Scandinavian countries by 2012; second, the application of the Baltic States to UCTE; third, construction of a new NPP in Lithuania "to satisfy the needs of the Baltic countries and the region an its inclusion in the electricity market of the region not later than by $2015^{\prime \prime 65}$. The implementation of these tasks requires cooperation between Lithuania and Poland.

\subsubsection{The Power Bridge between Lithuania and Poland}

Lithuania's plans to connect electricity transmission networks with Poland - to build Power Bridge between the countries - exist from 1993. The Power Bridge has a strategic importance for Lithuania. Firstly, it would increase stability of electricity supply in Lithuania - create an opportunity to import electricity after the decommissioning of the Ignalina NPP. Second, the connection would allow joining European internal market in electricity. In 2003, the study on project financing, which was sponsored by IPA-EBRD, it was advised to build interconnection with back-to-back converter (1000 MW of power). ${ }^{66}$ Polish side delayed the project due to fear of the import of cheap electricity produced at the Ignalina NPP. Later, when a decision on the closure of the Ignalina NPP was made and the fear of "cheap Lithuanian electricity" had to disappear, Polish energy experts have started to worry about cheap Russian electricity that would reach Poland through Lithuania. ${ }^{67}$ Due to increased competition it would be difficult for electricity generation companies of Poland to develop. Poland, eventually, could lose its strong positions of the exporter of electricity. It is profitless to Poland to allow Lithuania becoming the transit country of electricity to Poland, because it could threaten Poland's energy security (independence in the electricity sector). Power Bridge in Poland is not treated as the gates to Western Europe for the Baltic States, it is rather Russia's gates to Poland.

On the other hand, Power Bridge between Poland and Lithuania is not a

\footnotetext{
${ }^{65}$ Resolution on the Approval of the National Energy Strategy.

${ }^{66}$ The price of project was evaluated 434 million Euros. In purpose to make the project cost-effective, financial support of 267 million Euros from EU was needed. Juozaitis R., Ilgas lietuviškos elektros kelias ¿ Vakarus [Long way of Lithuanian electricity to the West], http://neris.mii.lt/mt/straipsniai/20055/ilg.doc, 20070909 (in Lithuanian).

${ }^{67}$ Komaras J.J., "Lenko pozicija: kodèl nėra elektros tilto i Vakarus?” [Position of the Polish: why there is no power bridge to the West?]. Lrytas.lt, 200603 14, http://www.lrytas.lt/ ?id=11422625581141696756\&view=4, 20070115 (in Lithuanian).
} 
bilateral issue. After connection of networks, Baltic Ring - connecting the Baltic countries, Scandinavia, Poland and Germany - would be completed. This is the major reason why project was included into the Priority Interconnection Plan. UCTE enlargement to the East is treated as an important opportunity for EU to expand the trade in electricity and transmission capacities. ${ }^{68}$ It cannot be accomplished without connecting the Baltic States to UCTE. Therefore the Power Bridge facilitates the development of internal market in electricity as well as the trade with neighbouring countries.

Moreover, not the Baltic countries or Lithuania would become the main transit corridor from UPS/IPS to UCTE. Such a perspective belongs to Poland. It is foreseen, that trade between EU and Belarus, Ukraine, and Russia will reach 40 TWh per year in 2030, among the Baltic States, Finland, and Russia - 30 TWh per year ${ }^{69}$. The lion's share of the trade between Western Europe and Russia and/or Ukraine will pass Poland. The main difference between Lithuania's and Poland's Power Bridge and wide UCTE-UPS/IPS interconnection is that Lithuania becomes the transit country in the case of Power Bridge and Poland potential consumer. If UCTE and UPS/IPS are interconnected through Belarus and Ukraine and capacity of the transmission networks in Poland are increased, Poland will become the transit country, consumers - other states of Western and Central Europe. Probably this was the reason why the decision had been made to modify the Power Bridge project and include the expansion of the transmission networks in Poland and the interconnection between Poland and Germany. ${ }^{70}$ Exploiting the necessity to link the Baltic States to Western European grids, Poland seeks to solve its own problems in the electricity sector and neutralize potential threats to its energy security. On the other hand, even the latter modification has not improved the implementation of the project.

The project of interconnection line between Lithuania and Poland (including the upgrading of the Polish electricity network and the Poland-Germany section) is part of the Priority Interconnection Plan as "necessary in order to allow participation in the internal energy market"71 (see Map 8).

\footnotetext{
${ }^{68}$ European Commission, Directorate-General for Research, Energy Corridors. European Union and Neighbouring Countries, 2007, http://www.ecn.nl/docs/library/report/2007/b07016.pdf, 20070820.

${ }^{69}$ Ibidem.

${ }^{70}$ Priority Interconnection Plan.

${ }^{71}$ Ibidem.
} 


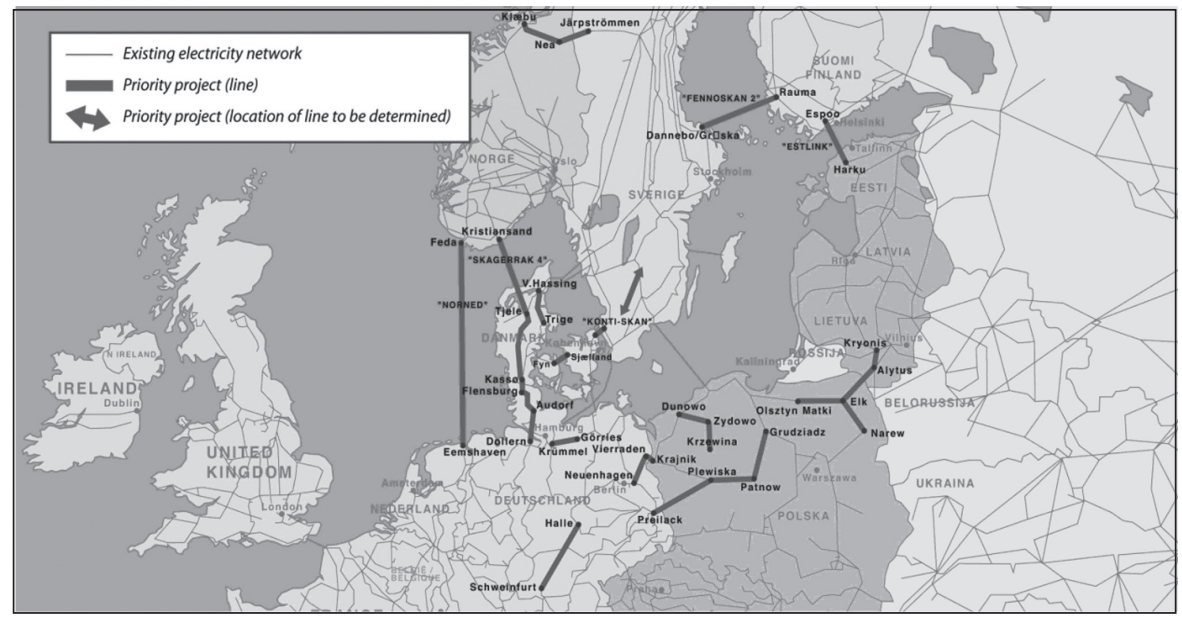

Map 8. Denmark-Germany-Baltic Ring ${ }^{72}$

Difficulties surrounding the implementation of the projects are indicated as following: first, the change in scope - its modifications, second, the lack of coordination and political will, third, uncertainties due to different synchronized areas, fourth, Polish grid stability and security, fifth, environmental concerns regarding the natural protected area crossed by the routing, sixth, the need for legal amendments to allow expropriating land for construction in Poland and others $^{73}$. Although a portion of these problems are technical in nature, the remaining are related to "the spirit of strategic partnership": lack of political will, legal amendments, environmental concerns and others. In September 2007 The European Commission even appointed a coordinator to facilitate and accelerate the implementation of the power connection linking Lithuania, Poland and Germany. ${ }^{74}$ To the opinion of the European Commission, most complicated for implementation part of the project is line Alytus-Elk (Lithuania-Poland) ${ }^{75}$ Then again, probably the most complicated part of the project is different geoenergetic interests of Lithuania and Poland.

In July 2007 Lietuvos Energija and Polskie Sieci Elektroenergetyczne signed the final feasibility study of the Project, which says that interconnection will cost about 240 million Euros and it will be feasible if EU funds $75 \%$ of the

\footnotetext{
${ }^{72}$ Priority Projects for Electricity, http://ec.europa.eu/ten/energy/studies/doc/2004_brochure/electricity_network_07_en.jpg, 20070812.

${ }^{73}$ Priority Interconnection Plan.

${ }^{74}$ BNS, Europos Komisija paskyre koordinatoriu energijos tilto iš Lietuvos i Lenkija projektui [The European Commission appointed coordinator for the project of power bridge from Lithuania to Poland], 2007 09 13, http://www.euro.lt/lt/naujienos/apie-lietuvos-naryste-europos-sajungoje/naujienos/1471/?print=1, 20070913 (in Lithuanian).

${ }^{75}$ European Commission, Directorate-General for Transport and Energy, Trans-European Energy Networks. 1st TEN-E Information Day, 200703 30, http://ec.europa.eu/ten/energy/documentation/doc/2007 03_30_ten_e_infoday_presentation_en.pdf, 20070815.
} 
project; additional investments into internal grids - 370 million Euros in Poland and 95 million Euros in Lithuania. ${ }^{76}$ The latter investments should be done by the attendees of the project - Lietuvos energija and Polskie Sieci Elektroenergetyczne. If Poland holds it position - the construction of interconnection only after upgrading internal networks - interconnection can never see the daylight. Moreover, Poland will have a leverage in its relations with Lithuania for pressure in other issues that are both related to energy and not.

\subsubsection{Construction of the New NPP in Lithuania}

Construction of new NPP in Lithuania is another important project of improving Lithuania's energy security. This task is in the National Energy Strategy. In June 2007 the Seimas passed the law on Nuclear Power Plant and cleared the way for the project ${ }^{77}$. The law had laid down the path to continuance of the nuclear energy in Lithuania.

The beginning of NPP project can be dated as February 2006, when the Prime Ministers of Lithuania, Latvia and Estonia signed the communiqué, in which they had expressed their support to the project and had invited national electricity companies to invest. Some week later heads of Lietuvos energija, Latvenergo and Eesti Energia agreed on the demand for feasibility study. Leaders of the Baltic States and their electricity companies are interested in the NPP, because all three countries is going to face electricity deficit after the closure of Ignalina NPP and the increased imports from Russia (or demand for the investments in electricity production in their countries). In the initial feasibility study it was concluded, that, comparing with other options, construction of new NPP is best solution, because, first, the balance of primary energy resources could be sustained, second, the security of supply could be strengthen, third, environmental pollution could be reduced, fourth, the project is cost-effective. ${ }^{78}$ It was advised in the study to construct 800-1600 MW of power NPP. The decision of the Baltic States to cooperate on the project matches the global and EU trend to develop nuclear energy.

An evolution of the project was changed at the end of 2006, when the Prime Ministers of the Baltic countries and Poland agreed on Poland's entrance

\footnotetext{
${ }^{76} \mathrm{BNS}$, Lietuvos ir Lenkijos elektros tiltas apsimokès, jei ES dengs 75 proc. investiciju [Power bridge of Lithuania and Poland will be feasible, if EU covers 75\% of investments], 200707 31, http://www.euro. 1t/lt/naujienos/apie-lietuvos-naryste-europos-sajungoje/naujienos/1219/, 20070802 (in Lithuanian). ${ }^{77}$ Seimas of the Republic of Lithuania, Lietuvos Respublikos atomines elektrines istatymas [Law of the Republic of Lithuania on nuclear power plant], X-1231, 200706 28, http://www3.lrs.lt/pls/inter3/dokpaieska.showdoc_1?p_id=301267, 20070710 (in Lithuanian).

${ }^{78}$ Naujos atominés elektrinès statybos Lietuvoje igyvendinamumo studijos rezultatu apibendrinimas [Summary of the results of the feasibility study on the construction of the new nuclear power plant in Lithuania], 200610 25, http:/www.lpc.lt/repository/Summary\%20Report\%20for\%20Media\%20-\%20LT. pdf, 20070813 (in Lithuanian).
} 
to the project. ${ }^{79}$ Baltic countries saw the linkage between Poland's involvement in the NPP project and the speed of development of the interconnection between Poland and Lithuania. ${ }^{80}$ Second argument was reduced costs for participants and third - the possibility to build more powerful plant. Poland's decision is probably based on the following interests: first, to invest in the electricity generation in the Baltic States; second, an opportunity to get an experience in nuclear energy, which can be applied in the future in Poland; ${ }^{81}$ third, to guarantee that electricity, which will flow through the interconnection, will be produced in the plant that belongs also to Polish company; fourth, to satisfy the demand for electricity in the Eastern regions and increase the exports to the Central and Western Europe.

After Poland's intentions were declared and accepted, the power of projected NPP was increased to $3200 \mathrm{MW}$. At the same time an ultimatum from Warsaw had reached Vilnius with the claim for one third of the electricity produced in the NPP (1200 MW), otherwise Polish companies would leave. ${ }^{82}$ Such a quantity of electricity would allow Poland the loading interconnection with relatively more expansive electricity from the NPP (than from Russia), which, in addition, belongs to Polish investors. One third of shares in the project guarantees the same number of votes as Lithuania's and would reduce portfolio of Latvia and Estonia. The NPP project virtually would be Lithuanian-Polish with Latvia and Estonia as junior partners. Considering Lithuania's experience of "strategic partnership with Poland", the project can end in failure. In the case other partners accept Poland's claims, Poland will get 1200 MW, while the Baltic States the remaining 2000 MW. Taking into account initially projected power of $1600 \mathrm{MW}$, Poland is unnecessary partner. However, then the interconnection project would be threatened and this circumstance once again reminds about Warsaw's capabilities to manipulate Lithuania's requirements for the energy security.

\footnotetext{
${ }^{79}$ Naujos atominès elektrinès statyba. Projekto chronologija [Construction of the new nuclear power plant. Chronology of the project], http://www.lpc.lt/lt/main/atom/Events_nuclear, 20070901 (in Lithuanian).

${ }^{80}$ Pakalkaitė V., "Lenkų bilietas ị Ignaliną - ir elektros tiltas" ["Ticket of the Polish to Ignalina - power bridge too"], Verslo žinios, 200701 09, http://vz.lt/Default2.aspx?ArticleID=79a120d9-7ac6-4912-a499c129d1ab9edf, 20070215 (in Lithuanian).

${ }^{81}$ The Prime Minister of Poland Jaroslaw Kaczynski has mentioned plans to develop nuclear energy in Poland even in his inauguration speech at the Parliament on July 2006. For example, see "World Nuclear Review - Week Ending 21st July 2006“, The Nuclear Communication Network, No.29/06. http://www. analys.se/lankar/Internat/NucNet/internatNucRew29_06.htm, 20070215.

82 "Pokalbyje dèl naujos elektrinès - Lenkijos spaudimas" ["At the discussions on new power plant - Poland's pressure"], Bernardinai.lt, 200707 21, http://www.bernardinai.lt/index.php?url=articles/65476, 20070725 (in Lithuanian).
} 


\section{Relations between Lithuania and Poland in the Oil Sector}

The entire EU, especially after enlargement in 2004, becomes a huge oil refining area, connecting Russia with North America: one third of oil imports come from Russia, while one fourth of exports of petroleum products- to the US $^{83}$. Lithuania and Poland do not fit EU average. Lithuania imports oil from Russia, and refines and exports petroleum products mainly to the Western Europe. Therefore Lithuania can be described as an oil refiner between Russia and the Western Europe. Poland does not belong to the group of refiners, connecting Russia and the remaining Europe -its refining capacities are not sufficient even for internal demand. On the other hand, both Lithuania (till 2006) and Poland are transit countries of Russia's oil to the Western Europe.

\subsection{Oil industries in Lithuania and Poland}

\subsubsection{The Main Trends in the Oil Sectors of Lithuania and Poland}

Oil consumption in Lithuania was more stable than in Poland for the last ten years - in Poland oil consumption has risen 30\% (see Figure 6). Increased demand in Poland does not allow expanding export of petroleum products, it is even on contrary - Poland imports petroleum products. Strongest side of Lithuania's oil industry is refining of oil and export of petroleum products (see Table 4). In 2006 Lithuania imported only 2.5 times less oil than Poland and exported 2 times more petroleum products.

\footnotetext{
${ }^{83}$ Kröppl C., “Oil Economy 2006”, Eurostat Data in Focus, 13/2007, http://epp.eurostat.ec.europa. eu/cache/ITY_OFFPUB/KS-QA-07-013/EN/KS-QA-07-013-EN.PDF, 20070823.
} 


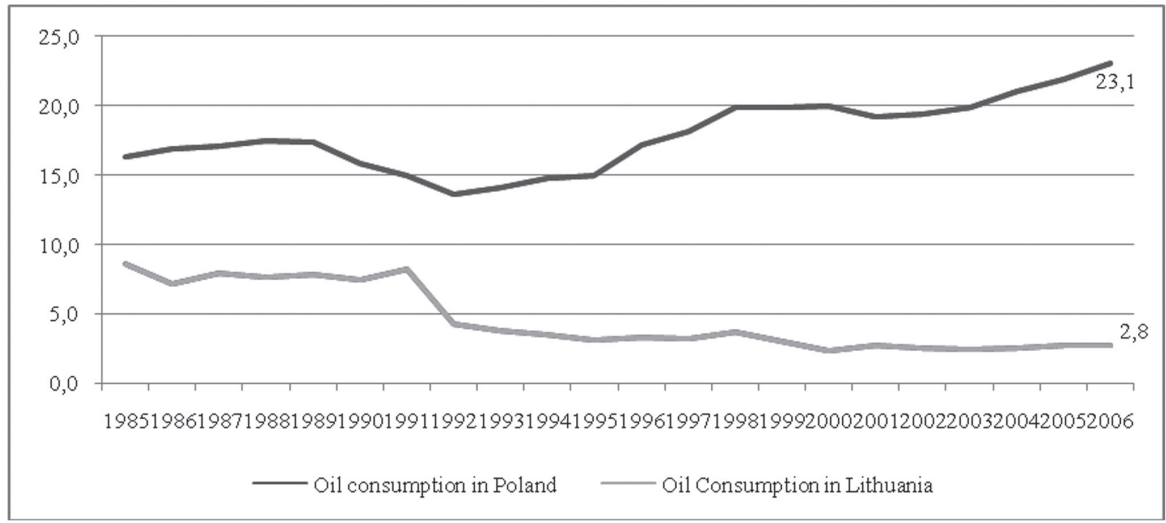

Figure 6. Oil Consumption in Lithuania and Poland ${ }^{84}$

However oil refining and exports of petroleum products are decreasing in Lithuania. The main cause of unstable oil refining is relations between owners of oil refinery Mazeikiu nafta and oil suppliers - Russia's oil companies.

Table 4. Oil dependency in Lithuania and Poland in thousand tons ${ }^{85}$

\begin{tabular}{|c|c|c|c|c|}
\hline & & & Lithuania & Poland \\
\hline \multirow{16}{*}{ Crude Oil } & \multirow{4}{*}{ Production } & 2004 & 302 & 879 \\
\hline & & 2005 & 216 & 857 \\
\hline & & 2006 & 180 & 769 \\
\hline & & $2006 / 2005 \%$ & -16.7 & -10.3 \\
\hline & \multirow{4}{*}{ Total Imports } & 2004 & 8756 & 17930 \\
\hline & & 2005 & 9000 & 18281 \\
\hline & & 2006 & 8518 & 20680 \\
\hline & & $2006 / 2005 \%$ & -5.4 & 13.1 \\
\hline & \multirow{4}{*}{ Total Exports } & 2004 & 193 & 178 \\
\hline & & 2005 & 147 & 237 \\
\hline & & 2006 & 116 & 283 \\
\hline & & $2006 / 2005 \%$ & -21.1 & 19.4 \\
\hline & \multirow{4}{*}{ Input to Refineries } & 2004 & 8682 & 18867 \\
\hline & & 2005 & 9227 & 18822 \\
\hline & & 2006 & 8251 & 21548 \\
\hline & & $2006 / 2005 \%$ & -10.6 & 14.5 \\
\hline
\end{tabular}

\footnotetext{
${ }^{84}$ The BP Statistical Review of World Energy 2007.

${ }^{85} \mathrm{Kröppl}$ (note 83).
} 


\begin{tabular}{|c|c|c|c|c|}
\hline \multirow{12}{*}{$\begin{array}{l}\text { Petroleum } \\
\text { Products }\end{array}$} & \multirow{4}{*}{$\begin{array}{l}\text { Total Inland Deliv- } \\
\text { eries }\end{array}$} & 2004 & 1907 & 19574 \\
\hline & & 2005 & 2022 & 19803 \\
\hline & & 2006 & 2059 & 21268 \\
\hline & & $2006 / 2005 \%$ & 1.8 & 7.4 \\
\hline & \multirow{4}{*}{ Total Imports } & 2004 & 441 & 5025 \\
\hline & & 2005 & 421 & 5527 \\
\hline & & 2006 & 498 & 5783 \\
\hline & & $2006 / 2005 \%$ & 18.3 & 4.6 \\
\hline & \multirow{4}{*}{ Total Exports } & 2004 & 6558 & 2334 \\
\hline & & 2005 & 6697 & 2496 \\
\hline & & 2006 & 6245 & 2851 \\
\hline & & $2006 / 2005 \%$ & -6.7 & 14.2 \\
\hline
\end{tabular}

A comparison of forecasts of oil consumption in Lithuania and Poland (see Figure 7) shows, that, firstly, oil consumption will increase by $2 \%$ annually in both countries. Second, oil production in Lithuania will grow by $2 \%$ per year, while in Poland production reaches its peak in 2015 and will decrease eventually. However production rate remains minimal in both countries - less than 1 million tons per year. Third, oil imports will increase significantly. In 2020 Poland's demand will be 6 million tons higher than in 2005, Lithuania's -2 million tons. Fourth, the growth of oil imports to Lithuania is a consequence of increased oil refining and exports of petroleum products. It is forecasted, that Poland will import more both oil and petroleum products. In 2020, if Lithuania redirects its exports of petroleum products to Poland, it will cover Poland's demand for imports of petroleum products.

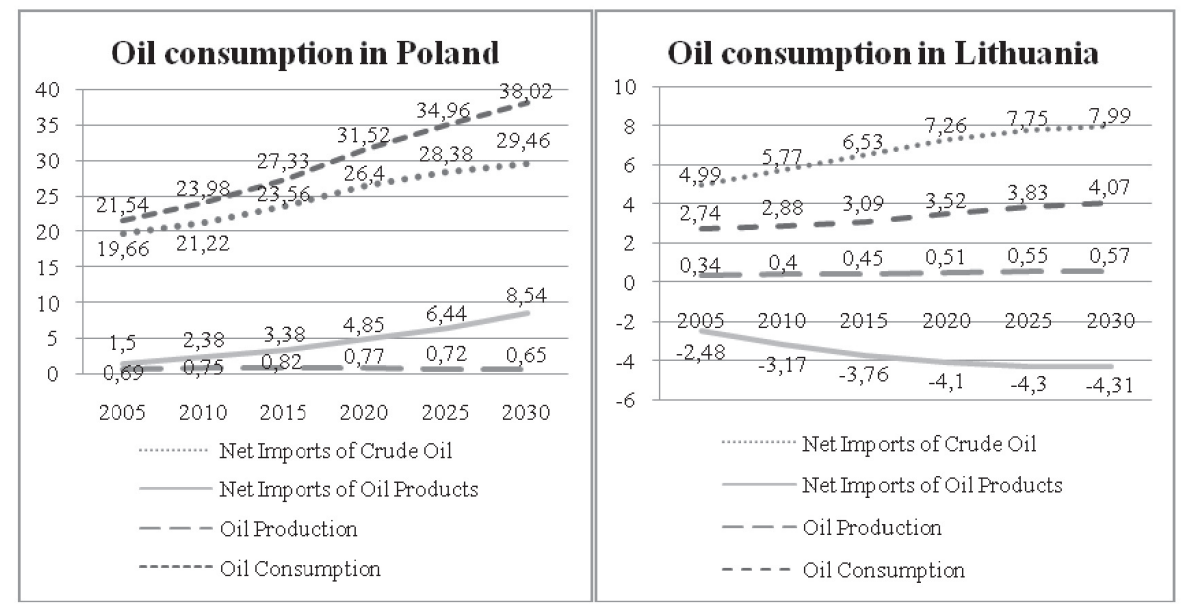

Figure 7. Oil Consumption in Poland and Lithuania in million toe ${ }^{86}$

\footnotetext{
${ }^{86}$ European Energy and Transport - Trends 2030 (note 25).
} 
The structure of the oil imports to both countries is similar (see Figure 8). In 2006 Lithuania imported 97\% of oil from Russia, Poland - 92\%. Export of oil from Russia decreased by 1\% in 2006 and amounted to 249.91 million tons. Accordingly exports to Lithuania and Poland made $10.36 \%$ of total exports (to Poland $-9.24 \%$ ). These numbers depict dependency of both countries on Russia. On the other hand, oil trade is more flexible than trade in natural gas due to wider variety of transportation (oil pipelines, rails, tankers) consequently amounts of trade may vary more.

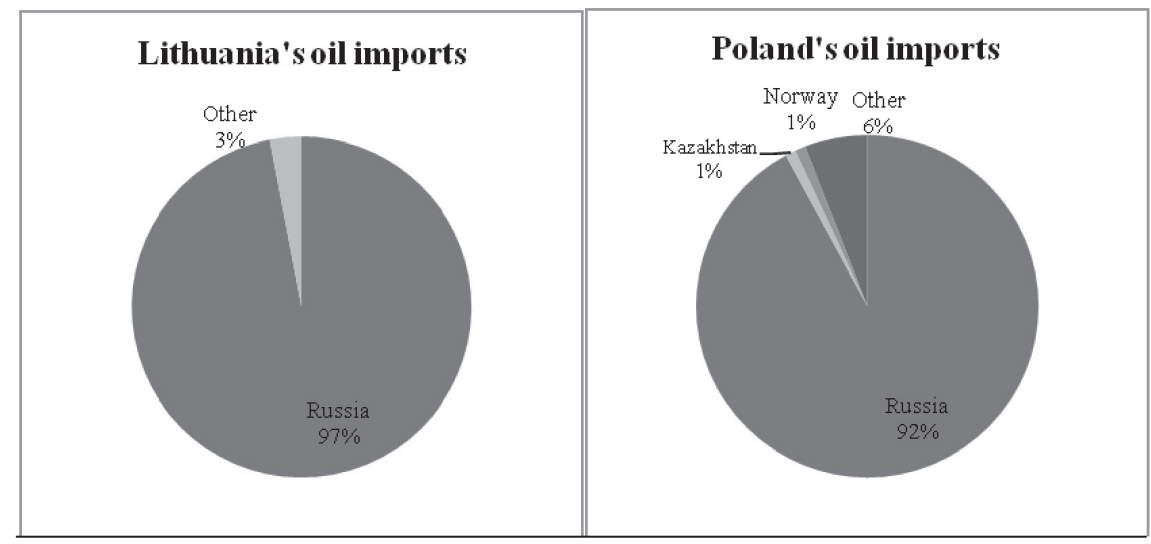

Figure 8. Lithuania's and Poland's Oil Imports ${ }^{87}$

Before PKN Orlen became an owner of Mazeikiu Nafta, Lithuania and Poland were competitors in the oil refining only in the short term - in the medium term Lithuania could turn into important supplier of petroleum products for Poland. This scenario would allow Poland diversifying imports of petroleum products. Naturally, diversification would be effective with one condition - Mazeikiu Nafta does not belong to Russia's oil companies.

\subsubsection{The Oil Transit through Lithuania and Poland}

Lithuania and Poland were competitors in the oil transit until the middle 2006. About 20-22 million tons of oil are annually transported through the Druzhba oil pipeline in Poland to Germany ${ }^{88}$ (see Map 9) - slightly more than Poland consumes (see Figure 6). About 10 million tons annually are exported from Gdansk. ${ }^{89}$

Till an accident in the branch of the Druzhba oil pipeline (see Map 9) Lithuania used to export 6-7 million tons of Russia's crude oil (7.1 million tons in

\footnotetext{
${ }^{87} \mathrm{Kröppl}$.

$\underline{88}$ AFP, Russian Oil Supplies to Poland, Germany Caught in Belarus Dispute, 200701 08, http://www. breitbart.com/article.php?id=070108124819.kkhgowaq\&show_article=1, 20070205.

${ }^{89}$ Baltic Maritime Outlook 2006. Goods Flows and Maritime Infrastructure in the Baltic Sea Region, March 2006, http://ec.europa.eu/transport/intermodality/motorways_sea/doc/potential/2006_03_baltic_maritime_outlook.pdf, 20070205.
} 
2004, 6.2 millions tons - 2005, 2.8 millions tons -2006$)^{90}$ - almost twice more than consumes. On July 29, 2006 an accident happened in the branch of the Druzhba oil pipeline (in the first line of Unecha-Primorsk) near Bryansk in the Russian Federation -48 cubic metres of oil (around 40 tons) spilled over. The pressure had been reduced in the pipeline and Lithuania was left without the oil. ${ }^{91}$ The Federal Ecological, and the Technological and Nuclear Supervisory Service (Rostechnadzor) made an investigation and has found 7853 failures in the pipeline, which has to be fixed before exploitation. In September 2007 Rostechnadzor confirmed its readiness to fix the pipeline if Transneft will sponsor it. ${ }^{92}$

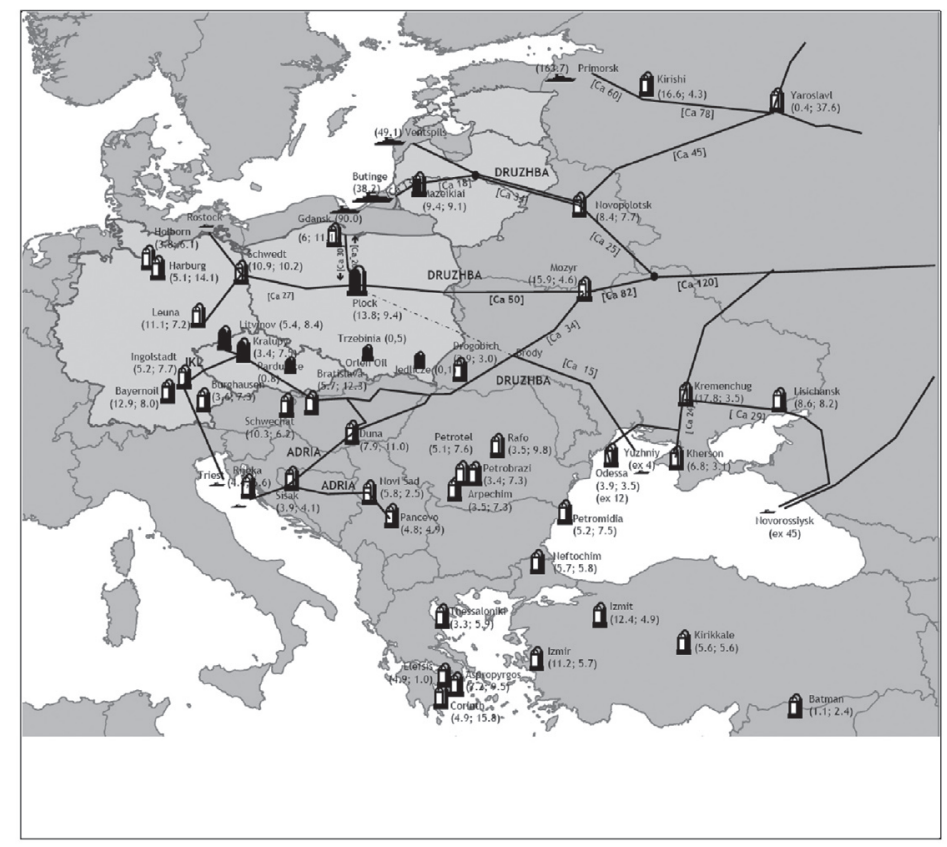

Map 9. The Oil industry and infrastructure in Central and Eastern Europe ${ }^{93}$

\footnotetext{
90 “AB” Mažeikiu nafta 2006 metu prospektas-ataskaita [AB Mazeikiu Nafta folder-report 2006], www. nafta.1t/get_file.php?id=117, 20070705 (in Lithuanian).

${ }^{91}$ Alike accidents (when spill is less than 100 tons) are not an extraordinary thing in the pipeline, which is 30-40 years old (first line of the Druzhba was built in 1968, second - 1974). Clear correlation between the age of pipeline and accidents is found in the Russia Pipeline Oil Spill Study, accomplished by UNDP and World Bank Energy Sector Management Assistance Programme. More than $30 \%$ of oil spills happen in the oil pipelines that are older than 20 years. See Joint UNDP/World Bank Energy Sector Management Assistance Programme, Russia Pipeline Oil Spill Study, April 2003, http://www.esmap.org/filez/pubs/ 03403RussiaPipelineOilSpillStudyReport.pdf, 20070205.

${ }_{92}^{2}$ Newsru, “Дружбе” конеи: трубопровод в Литву не будет отремонтирован [The end of the Druzhba: pipeline to Lithuania will not be fixed ], 200709 07, http:/www.newsru.com/finance/07sep2007/ druzhba.html, 20070907 (in Russian).

${ }^{93}$ Chalupec I., "Mažeikiu naftos” isigijimas - stiprios regioninès grupès Centrinèje Europoje formavimas [Acquisition of Mazeikiu Nafta - creation of strong regional group in the Central Europe], 20061215 , http://www2.orlen.pl/pub/files/MN_Closing_IR_v15122006_LT.pdf, 20070705 (in Lithuanian).
} 
The latter decision will allow us to make a presumption, that the oil pipeline will not be fixed and Lithuania will not remain a country of oil transit. Firstly, Russia follows the principle "Russia's goods to Russia's ports" - oil export is increased through Russia's oil export terminals, capacities of which are constantly increasing. About 7 million tons of oil that were exported through Lithuania were not significant to Russia. Second, Russia seeks to refine more oil and its territory and increase the exports of petroleum products. Third, Russia diversifies markets of oil exports to the East. Therefore, and particularly after the control of Butinge oil terminal was passed to the Polish company, Russia has no motives to fix an oil pipeline and renew oil transit through Lithuania. A loss of the oil transit was the price that Lithuania paid for "wrong" decision on the new owner of Mazeikiu Nafta.

Considering the age of the Druzhba oil pipeline, Russia is going to face more often a similar dilemma - whether to upgrade existing pipelines or build the new ones. Obviously, solution will depend on economic as well as geo-energetic arguments - relations between Russia, as a supplier, and transit and/or consuming countries. It can be forecasted, that a number of Russia's oil transit countries will decrease and as a result Poland can also become consumer instead of transporter as Lithuania did. Arguing on the technical condition of the pipeline Russia cut-off oil transit through Latvia in 2003 (the ability to increase export through Butinge had facilitated); when capacity of Primorsk oil terminal was increased - Lithuania's turn has come. If/when it is possible to redirect the oil from the Northern branch of the Druzhba oil pipeline, Belarus and Poland probably will be the next on the list to lose transit revenues as well as oil imports by oil pipelines from Russia. Moreover, Russia would gain additional tool for more effective "divide and rule" policy - Russian companies could choose among the 'most attractive' partners for trade in the Central Europe. There are some indications already that Poland will lose its role of oil transit country - Transneft has suspended oil export through the Gdansk oil terminal from the second quarter of $2007 .{ }^{94}$

\subsection{The Impact of PKN Orlen Investments on Lithuania's Energy Security}

\subsubsection{Reasoning of PKN Orlen investments in Lithuania}

A loss of oil transit function reduced an intensity of geo-energetic relations in the oil sector between Lithuania and Poland - transporters dependent on the same supplier. On the other hand, after PKN Orlen investments to Mazeikiu Nafta and the Butinge oil terminal ${ }^{95}$, the oil sectors of both countries became hardly separable. The prospects of oil refining in Lithuania will depend on

\footnotetext{
${ }^{94}$ Zhdannikov D., "Russia sets flat Q2 oil export schedule”. Reuters, 200703 21, http://uk.reuters.com/article/oilRpt/idUKL213035720070321, 20070515.

${ }^{95}$ In December 2006 PKN Orlen bought from Yukos International UK B.V. 53.7\% of shares for 1,492 billion USD and from the Lithuanian Government $-30.66 \%$ of shares for 0.851 billion USD. Portfolio of $84.36 \%$ in total cost 2,34 billion USD. The remaining shares are controlled by the Lithuanian Government $-10 \%$ and minority shareholders $-5.64 \%$.
} 
PKN Orlen abilities to guarantee oil supplies as well as strength of company's international positions - capabilities to compete in the Central and Eastern Europe, firstly, with the Hungarian MOL and Austrian OMV.

As PKN Orlen argues, it was the biggest tender in Poland's history. ${ }^{96}$ From the energy security point of view, it was more advantageous to Poland to buy Mazeikiu Nafta than for Lithuania to sell it. According to the management of PKN Orlen, reasoning to buy Mazeikiu Nafta was based on ${ }^{97}$, first, the natural outcome of company's development, looking for promising acquisitions and orienting to the markets that are expected to grow. Second, Mazeikiu Nafta is a high-complexity refinery and the only in the Baltic States. Third, crude oil and petroleum products pipelines as well as the Butinge oil terminal belong to Mazeikiu Nafta. Fourth, the market of Mazeikiu Nafta products covers the Baltic States, Western Europe and the US. On top of official goals additional ones can be added: strengthening of PKN Orlen positions in Poland and securing the Polish oil industry from the Russian companies. ${ }^{98}$

Control of Mazeikiu Nafta is a gate not only to the market of the Baltic States but to Poland's as well (especially considering growing demand for petroleum products in Poland). In the case Mazeikiu Nafta falls under the management of company that produces oil, the main target market of Mazeikiu Nafta will be Poland. Company that produces oil could reduce costs of refining (firstly because of lower price for crude oil) and compete effectively with companies that do not have their own reserves and production - PKN Orlen at the first place. If such an oil producing company was from Russia, threat for PKN Orlen would increase (in comparison, for example, with Kazakhstan's Kazmunaigaz), because Poland - market as well as its oil companies - was always an aim to Russian oil giants. In Poland some oilmen believed, that PKN Orlen would not be able to resist a competition and be driven to bankruptcy with eventual takeover from the side of Russian companies. ${ }^{99}$ For these reasons, the purchase of Mazeikiu Nafta was one of the key tasks enhancing country's energy security for PKN Orlen and the Polish Government. Similarly, in purpose to protect the interests of the energy security of Lithuania, this sale had to follow the key condition - that the refinery cannot be controlled by the supplier (the Russian oil companies). Otherwise Lithuania's oil sector would be challenged by attempts to monopolize entire industry and expansion of influence to the whole energy sector.

\footnotetext{
${ }^{96}$ Chalupec (note 93).

${ }^{97}$ Chalupec.

${ }^{98}$ More on PKN Orlen motives to buy Mazeikiu Nafta see BRE Bank Securities, PKN Orlen. Expansion to Lithuania, 200606 05, http://i.wp.pl/a/dibre/aspolek/pkn_050606_eng.pdf, 20070705.

${ }^{99}$ Komaras J.J., "Kodèl lenkai bijo rusų Mažeikiuose?" ["Why the Polish fear the Russians in Mazeikiai?'], Lrytas.lt, 200604 09, http://www.lrytas.lt/?id=11445789341142311187\&view=4, 20070825 (in Lithuanian).
} 


\subsubsection{Challenges to the Energy Security in the Oil Sector}

Conditions in the oil sector of Lithuania are most advantageous comparing with the remaining sectors (even after the loss of oil transit). Seeking to guarantee a stable functioning of the oil sector, Lithuania should be interested in the permanence of Mazeikiu Nafta owners - reducing the chances of the Russian companies to claim for greater influence in Lithuania. Guarantees of the possibilities of independent supply of petroleum products are second, the task of effectiveness and security. Lithuania can satisfy its demand for petroleum products whether from Mazeikiu Nafta or by import. If Mazeikiu Nafta, due to some causes, suspended operation, capabilities of a diversified and flexible import of petroleum products would allow securing stable supply.

After prevention of the threats from the North East PKN Orlen can more safely expand its influence in the Central Europe, where two other competitors are active - Hungarian MOL and Austrian OMV (see Figure 9). The results of competition of three companies will define the future of Mazeikiu Nafta too (PKN Orlen investment capabilities at the first place). From the positions of the energy security it is important for Lithuania that major shareholders of Mazeikiu Nafta would remain the same - basically, that PKN Orlen would not be forced to sell Mazeikiu Nafta at least in the medium term. Successful development of PKN Orlen should concern Lithuania no more than company's capabilities to implement its investment commitments. Obviously, this motivation could change, if Lithuanian Government had decided to become shareholder of PKN Orlen. However, the latter decision is hardly feasible. 


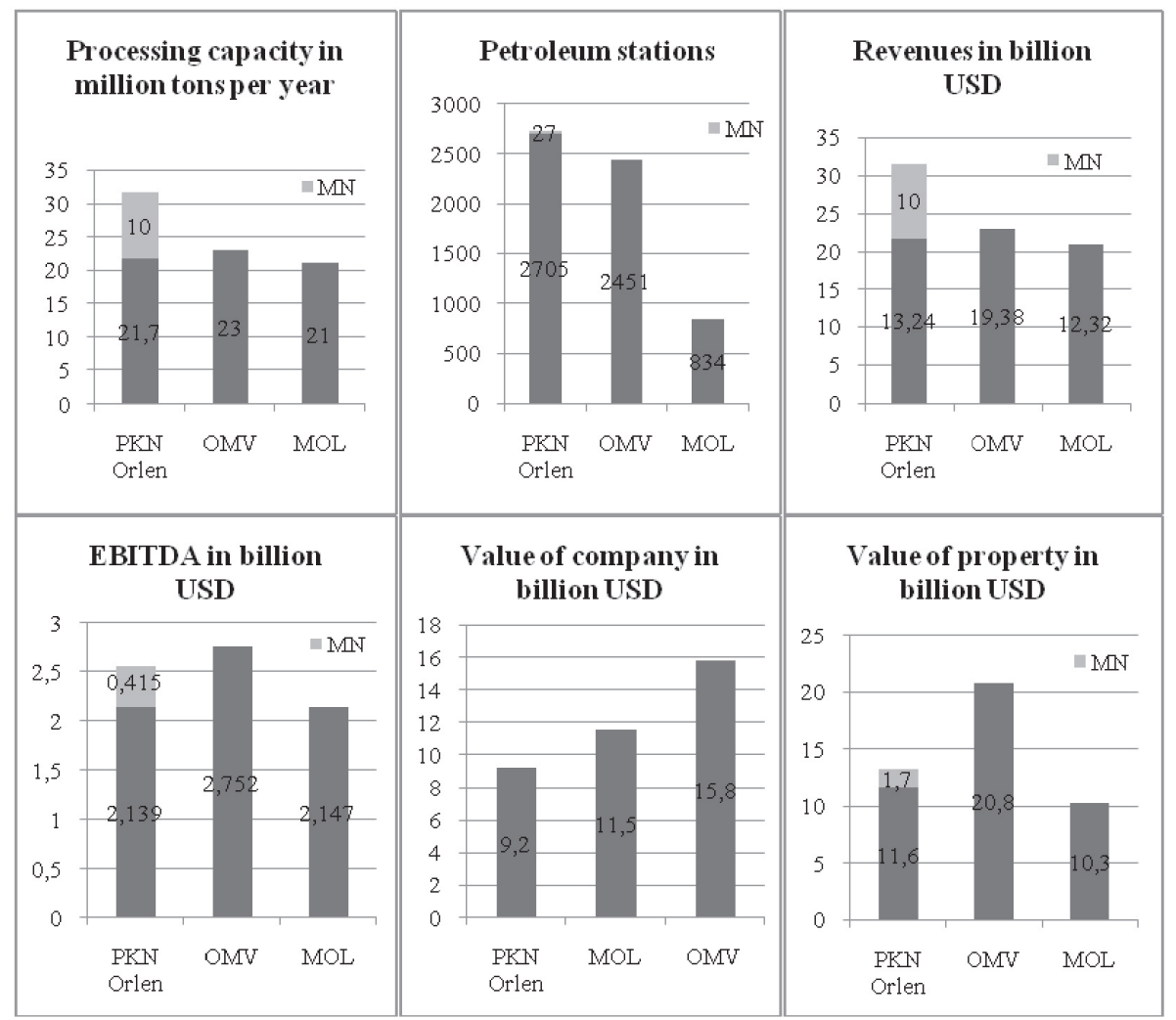

Figure 9. Comparison of PKN Orlen, OMV, and MOL Performance in $2005^{100}$

PKN Orlen can further develop in at least three directions: first, strengthening of its positions in Poland, second, buying new assets in the Central and Eastern Europe, third, the merge with the other company in the Central and Eastern Europe. Strengthening of PKN Orlen positions in Poland is linked to the plans of merge with state controlled (51.9\% of shares) Lotos Group, which holds Gdansk oil refinery and 400 petroleum stations. This prospect is supported by PKN Orlen managers. ${ }^{101}$ Capitalization of merged companies would reach 13 billion USD ${ }^{102}$ and would outreach the one of MOL (see Figure 9). Second direction - buying assets of companies that refine oil and/or trade petroleum products in the Europe - is vaguer due to lack of attractive tenders. Third direction - merge with other oil company. This issue was already discussed

\footnotetext{
${ }^{100}$ Chalupec.

${ }^{101}$ Interfax, Polish PKN Orlen plans to merge with Lotos, no Warsaw listing for Czech Unipetrol, 200709 04, http://www.interfax.com/5/309376/news.aspx, 20070905.

102 "PKN Orlen ambicijos" [“Ambitions of PKN Orlen”], Versus, 200705 07, http://www.lrytas. lt/?id=11785581771176340376\&view=4\&p=4, 20070905 (in Lithuanian).
} 
among PKN Orlen and MOL managers as well as the leadership of Poland and Hungary. After the amalgamation, capitalization of the new company would be more than 20 billion USD; giant would have petroleum stations in Poland, Hungary, Czech Republic, Slovakia, Germany and Lithuania. Alike company could resist pressure not only from Austrian MOL, but Russian oil majors as well. It would also facilitate consolidation of the refining area of the Central Europe. Once again, merge with MOL should concern Lithuania as much as it is related to the ownership of Mazeikiu Nafta, investment commitments, and capabilities to satisfy internal demand for petroleum products.

As it was mentioned before, Lithuania can satisfy its demand for petroleum products whether from Mazeikiu Nafta or by imports. Lithuania can import petroleum products whether by rail or through Klaipedos Nafta petroleum products transhipment terminal. Considering the fact, that maritime transport is more flexible and allowing diversifying suppliers, it is important to Lithuania securing control of the latter. The National Energy Strategy says that Lithuania "has achieved diversification in the supply of petroleum products and is technically secured against possible supply disruption from any one country. Lithuania has sufficient transportation, processing, storage and distribution capacities to meet the demand in petroleum products." 103

Controlling the stake $(70.6 \%)$ of Klaipedos Nafta belongs to the Lithuanian Government. Company holds import-export petroleum products terminal, which capacity exceeds Lithuania's demand - 7.1 million tons per year. In 2006 the terminal loaded 5.5 million tons of petroleum products. The main client of Klaipedos Nafta is Mazeikiu Nafta $(76 \%$ of loaded products). ${ }^{104}$ Therefore results of Klaipedos Nafta activity depends on refining and export capacities of Mazeikiu Nafta. On the other hand, potentially the terminal could shift to imports of petroleum products and as in the case Mazeikiu Nafta, disrupt its operations. Moreover, Klaipedos Nafta could be used as an oil import terminal for Mazeikiu Nafta itself. Possibility to be exploited as multifunction facility and the ownership by the state makes Klaipedos Nafta a balancer and stabilizer of the market of petroleum products. Changes of the owners of the terminal could harm this flexibility: if Klaipedos Nafta was controlled by the Russian companies, they would (depending on relations with PKN Orlen) whether increase export of petroleum products and eventually limit the export of Mazeikiu Nafta or import petroleum products to Lithuania and eventually compete with the products of Mazeikiu Nafta. If the owner of Klaipedos Nafta terminal is the same as one of Mazeikiu Nafta, he/she could control the entire oil industry (import, refining, and export). Taking into account PKN Orlen ambitions to control from 30 to $50 \%$ of the market of the petroleum products in the Baltic States, company's intentions to buy Klaipedos

\footnotetext{
${ }^{103}$ Resolution on the Approval of the National Energy Strategy.

${ }^{104}$ AB “Klaipedos nafta”, Metinis pranešimas 2006 m. [Annual report 2006], March 2007, http://www.oil. 1t/uploads/media/Metinis_pranesimas_2006_patvirtintas.pdf, 20070705 (in Lithuanian).
} 
$\mathrm{Nafta}^{105}$ should be considered very cautiously. Consequences of the loss of the ownership probably would be followed by the dominant company in the oil industry and the deficit of guarantees that are mentioned in the National Energy Strategy.

\subsubsection{Projects of Oil Pipelines that Influence Energy Security of Lithuania and Poland}

On purpose, to secure refining quantities, PKN Orlen has to buy 30 million tons of oil per year. If all this oil came from Russia, it would make $12 \%$ of Russia's oil exports and become a quite significant factor in the negotiations. On the other hand, "negotiating positions of PKN Orlen are weak due to undiversified system of supply - dependence on Russia (see Map 10). Taking into account Russia's aim to diversify its oil exports, PKN Orlen may face problems of oil shortage. However they are more feasible for the refineries that do not have capabilities to import oil through maritime terminals than to Mazeikiu Nafta or similar refineries.

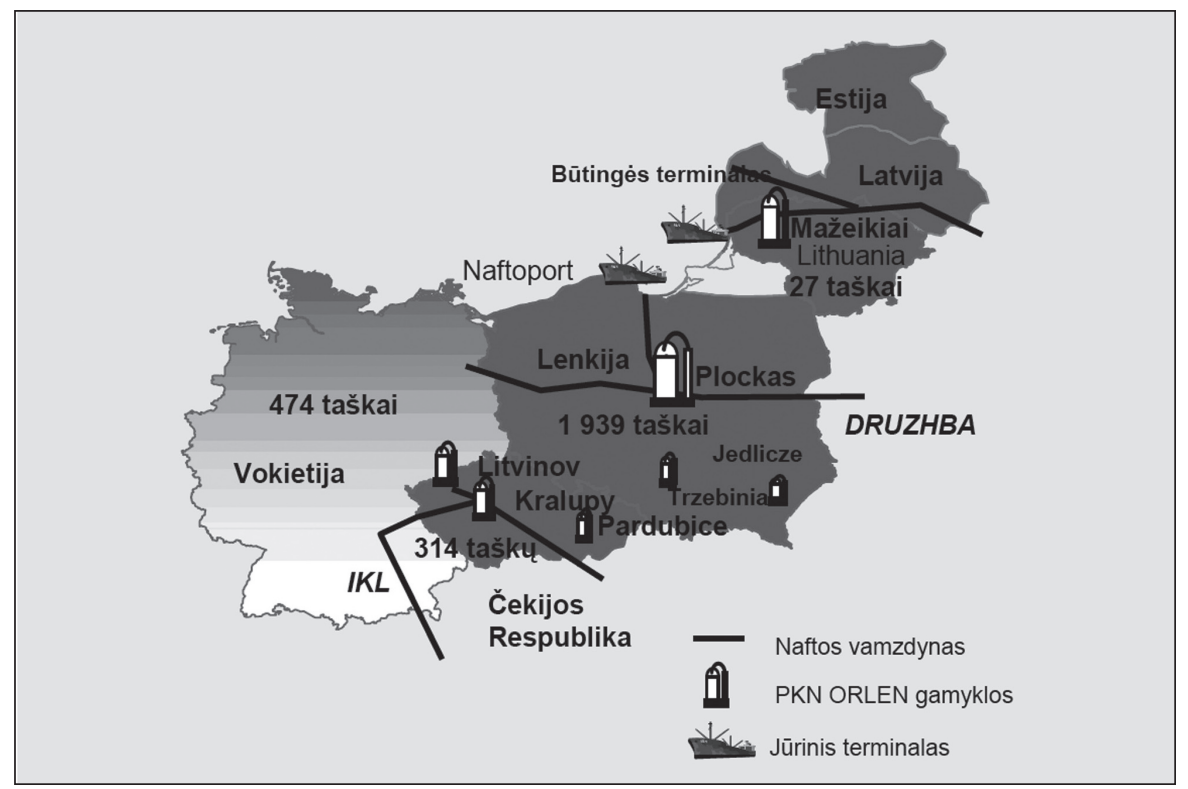

Map 10. Infrastructure controlled by PKN Orlen ${ }^{106}$

105 "PKN Orlen” taikinys - "Klaipėdos nafta" ["Target of PKN Orlen - Klaipedos Nafta"], Balsas.lt, 2007 03 28, http://balsas.lt/naujienos/verslas/straipsnis68637, 20070822 (in Lithuanian).

${ }^{106}$ Chalupec. 
Companies controlled by PKN Orlen and all the countries in the Central Europe may face disruptions of oil supplies, if Russia implements its attempts to bypass unnecessary intermediates - countries that the Druzhba oil pipeline passes through. It is hardly feasible that the supply of oil could be stopped at all, however quantities of transit may decrease and conditions of supply - change. Such a bypassing project is Baltic Pipeline System 2 (BPS-2) - construction of the oil pipeline from Unecha to Primorsk and expansion of the capacities of the oil terminal in Primorsk (see Map 9). After a conflict between Russia and Belarus for the oil price, taxes sharing schemes, and transit tariffs in 2007, Russia's oil pipeline monopoly Transneft had prepared anti-crisis programme. One of its items is the construction of BPS-2. ${ }^{107}$ The length of the oil pipeline will be 1157 $\mathrm{km}$, the price -2.5 billion USD. ${ }^{108}$ For this price Russia buys an opportunity, first, to keep empty the oil pipeline to Lithuania; second, reduce and eventually cancel oil export through the Druzhba branch in Poland; third, manipulate volumes of oil exports among all the branches and transit countries of the Druzhba oil pipeline; fourth, the increase the price of oil. If constructed, the new oil pipeline would be a major challenge to Poland - it can be forced to import oil through the terminals that are used for the export now (as it happened with the Butinge oil terminal). This would eventually increase the price of oil and diminish competitiveness of PKN Orlen. In contrary to Poland's, conditions of Lithuania's energy security would remain the same.

An alternative to the described unoptimistic one are Poland's plans to diversify oil imports by oil pipelines and attract the oil from the Caspian Sea. The latter task was given to the project of Odessa-Brody-Plock oil pipeline. Further construction of Odessa-Brody oil pipeline ${ }^{109}$ to the oil refinery in Plock (Poland) and forward to Gdansk could allow Ukraine and Poland diversifying imports and becoming important transit countries between the

\footnotetext{
${ }^{107}$ Newsru, Россия может быстро построить трубу в обход Белоруссии и отказаться от поставок нефти в Литву [Russia can quickly build a pipeline bypassing Belarus and deny oil supply to Lithuania], 200702 13, www.newsru.com/finance/13feb2007/vainshtock.html, 20070610 (in Russian). Capacity of the pipeline in the initial phase is going to be 50 million tons, while loading capacity of Primorsk to be increased till 130 million tons per year. In 2007 The Russian Government committed Ministry of Industry and Energy and Transneft to implement project in 18 months - till 2009. Newsru, "Дружба" врозь - правительство одобрило план строительства обходного нефтепровода [Druzhba smashed - government approved the plan of construction of bypassing pipeline], 20070522 , www.newsru.com/finance/22may2007/druzhba.html, 20070610 (in Russian).

${ }^{108}$ ИA Regnum, Вайншток: Стоимость проекта БТС-2 - около 2,5 млрд долларов [Vaynshtok: The cost of BPS-2 - about 2,5 billion dollars], 200706 10, www.regnum.ru/news/841614.html, 20070610 (in Russian).

${ }^{109}$ Odessa-Brody oil pipeline was finished in 2001 (length $-674 \mathrm{~km}$, capacity - 14,5 million tons). It was supposed to facilitate oil export from the Caspian Sea to Europe bypassing Russia. From Brody (connecting point with the Druzhba pipeline) oil had to be transported to oil refineries in the Western Ukraine (4 million tons per year) and the rest through the Druzhba to Slovakia, Hungary, Czech Republic, and Croatia. Pipeline was virtually empty till 2004, when Ukrtransnafta decided to reverse the line and export Russia's oil through Odessa instead.

For example, see Нефтегазовые проекты. Oдесса-Броды [Oil and gas projects. Odessa-Brody], www. oilcapital.ru/info/projects/63395/private/71862.shtml, 20070829 (in Russian).
} 
Caspian Sea and the Western Europe. However the key challenge remains neither Azerbaijan nor Kazakhstan can guarantee sufficient supply for the new pipeline. Azerbaijan cannot produce enough oil even for Baku-TbilisiCeyhan oil pipeline (from Azerbaijan to Turkey). Kazakhstan diversifies its exports to the East - oil export capacities are limited to the West. In addition, Kazakhstan does not want confrontation with Moscow for Ukraine or Poland, because country is dependent on the transit through Russia. Therefore, even if the project is implemented, Lithuania will not have any direct consequence on its energy security. It could affect them only indirectly - Lithuania would be isolated from the developing alternative to Russia's oil infrastructure. On the other hand, it could be easier to PKN Orlen securing supplies, so company's chances to survive would increase.

\section{Conclusions}

The natural gas sector has a different significance to the energy sectors of Lithuania and Poland. It is more important to Lithuania's geo-energetic position, because, first, the natural gas constitutes a bigger share in the balance of the primary energy resources. Second, Lithuania is totally dependent on a single natural gas supplier - Russia. The major difference between Lithuania and Poland is that Poland is the transit country of natural gas from Russia to the Western Europe (Germany) and this strengthens its advantage vis-a-vis Lithuania, which can be attributed to consumers. Poland has more instruments and leverages in the negotiations with Russia for the price and conditions of the supply of natural gas. The gas pipeline networks of Lithuania and Poland are not directly interconnected. Both countries are united only by the dependence on natural gas imports from Russia. However, Lithuania consumes insignificant quantities of natural gas and cannot compete with Poland as equal consumer. Geo-energetic relations between Lithuania and Poland can be described as of little significance in natural gas sector.

Lithuania's relations with Russia (dominant supplier) can be qualified as takeover of the control-Gazprom totally controls gas supply to Lithuania, holds one third of the shares of Lietuvos Dujos and can prevent any project that plans an alternative gas pipeline to Lithuania. Poland's (transporter) relations with Russia (supplier) develop as between equal actors. Russia depends on transit through Poland and together with partners (Western European consumers) has intentions to reduce this dependency - i.e. develops an alternative infrastructure that bypasses Poland. Poland acts in opposite way - increases transit capacities and obstructs close cooperation between supplier and consumer that bypasses Poland (supplier and consumers share the same interests towards transit countries).

It is hardly feasible that Lithuania and Poland will ever be interconnected by any gas pipeline. The transit routes will not run through the territories of 
these countries. Therefore Lithuania's attempts to become a country of natural gas transit from Russia to the Western Europe are ungrounded. Transit routes may cross only Poland in the long term. Possibilities to join the projects that could be implemented in Poland and facilitate diversification of supply are also overvalued in Lithuania. If transit capacities are not to be developed in Poland, country probably will transform from equal transporter to the consumer in relations with dominant supplier - as Lithuania. Relations among consumers in the field of the diversification of supply are based on competition for suppliers as well as routes. This is why Poland would be interested in connecting gas pipelines with Lithuania only if it guaranteed a restoration of the role of transporter. Consumption of natural gas in Lithuania will never achieve at the size to be significant enough to Poland's energy security.

Lithuania has to diversify import routes and sources and develop its transit function autonomously and independently from Poland. Natural gas will not reach Lithuania through alternative gas pipelines or through existing pipelines but different suppliers. Therefore probably construction of LNG terminal in Lithuania is the only real option for diversification of supply. In the transit field Lithuania should create favourable conditions for the natural gas supply to the Kaliningrad District and prevent any attempts to bypass Lithuania supplying gas to exclave. None of these directions of an improvement of Lithuania's energy security in natural gas sector is necessarily based on close geo-energetic relations with Poland.

The conditions of the electricity sectors of Lithuania and Poland differ as well. Lithuania is supplier of electricity only till 2010, while Poland will remain in this role. As it is in the natural gas sector, Lithuania's and Poland's relations in the electricity sector are not meaningful in geo-energetic sense. Although both countries are exporters of electricity, they are not interconnected and supply electricity to different consumers (Poland belongs to UCTE and Lithuania - UPS/IPS). The shape of relations between neighbours in the electricity sector does not have direct outcomes on their energy security.

Relations would evolve if electricity transmission grids were connected or countries supplied electricity to the same consumers. Implementation of Power Bridge project between Lithuania and Poland could bind electricity sectors of both countries. However it is natural that it has not happened, because relations between Lithuania and Poland would be as between equal suppliers - competition for consumers and access to the transmission networks. An interest of every supplier is to avoid competition - eventually Poland's decision to delay the project is understandable and reasonable.

After the decommissioning of the Ignalina NPP Lithuania will become a consumer in relations with dominant supplier of electricity. However even then it will not be useful to Poland's energy security to allow connecting electricity networks, because Lithuania would have an opportunity to strengthen its transit role and become a transporter of Russia's electricity to Poland. This scenario would facilitate Lithuania's position due to possible cooperation with both consumer and supplier; while impede the one of Poland - weaken 
its role of supplier. Poland would also become dependent on Lithuania. In the case where there were no other options except building the connection, the most safe option for Poland is to develop and expand the electricity transit and to become a transporter. Poland would be forced to compete with other countries of the Central Europe for transit. Lithuania's 'strategic partner' probably prepares for similar scenario - upgrades its transmission networks and connections with Germany.

After becoming consumer of electricity energy security policy should include at least three following directions: first, the diversification of suppliers and routes, second direction - the expansion of transit - making supplier dependent on Lithuania and third - increasing the supply. An increase of supply helps geo-energetic actor to enhance independence (decrease dependence on supplier(s)) or to become a supplier. Construction of the new NPP in Lithuania could sustain supplier's role. Poland's attendance in the project with preconditions requiring certain quantity of production is reasonable, because it could prevent Lithuania from becoming supplier to Poland and competitor. The loading of the Power Bridge would allow increasing the control over the connection and limiting Lithuania's chances to develop transit independently. Therefore, Lithuania should increase the role of transit from Russia to consumers (for example, Scandinavian countries) that are interested in diversification of suppliers as well as routes. While increasing supply Lithuania should avoid an involvement of those geo-energetic actors, relations with which cannot be advantageous and useful.

Poland is a transit country in the oil sector. Lithuania used to be a transit country till the middle of 2006. Although countries are not directly interconnected by infrastructure whether of crude oil supply or transit, they used to be equal competitors, because both transported oil from the same source-Russia. Russia's attempts to limit influence of transit countries, diversify the markets, increase refining in the country and develop export infrastructure bypassing transit countries fully match behaviour of typical supplier. It can be forecasted, that Poland will lose its role of transit country as Lithuania did and become consumer in the middle-long term.

After suspension of transit, Lithuania has remained a refiner. If Poland loses oil transit, it will not have the same option (to remain a refiner), because its demand for petroleum products already exceeds oil refining capacities. Due to these reasons Poland tries to exploit its transporters role and diversify suppliers as well as routes and increase independence - prevent Russia from becoming dominant supplier instead of equal one as it used to be. Russia's role of dominant supplier would threaten Poland's energy security. The Polish companies as well as the Government make the efforts to implement Odessa-Brody-Plock oil pipeline project and to become a transit country of Caspian oil - remain a transit country and diversify suppliers and routes. This pipeline is not about to reach the Baltic States, therefore Lithuania should not have an interest to attend the project. Second direction of Poland's energy security policy in the oil sector is to reduce supplier's ability to dominate relations. Russia would become a 
dominant supplier, if conditions for takeover of control of the oil sectors of the other geo-energetic actors were created - when other actors lost independence in their functions. Russia had disrupted the oil transit through Lithuania and tried to create the conditions for takeover of Mazeikiu Nafta. The control of oil refining in Lithuania would allow making influence on Poland's oil sector, which is dependent on imports of petroleum products. Therefore PKN Orlen decision to anchor in Lithuania decreased an intensity of threats to Poland's energy security at least in the oil sector.

Lithuania's energy security in the oil sector depends on effective prevention of monopolization of the oil sector and changes in the ownership of Mazeikiu Nafta. One of the instruments of prevention of monopolization of petroleum products market is control of Klaipedos Nafta (crude oil and petroleum products terminal). Only PKN Orlen has capabilities to monopolize petroleum products market, accordingly Lithuanian Government should not allow the Polish company acquiring this strategic facility. Changes in the ownership of Mazeikiu Nafta would threaten Lithuania's energy security if the refinery passes to supplier - Russia's companies, which already have significant influence on the processes in Lithuania's energy sector.

Strategic partnership is feasible only between those geo-energetic actors that cooperate. Preconditions for cooperation are meaningful relations in geoenergetic sense, equality of geo-energetic actors, which have complementary functions in one sector or entire energy field. Lithuania and Poland have intense enough relations only in the oil sector, but they are not based on cooperation. There are no meaningful relations in the electricity or natural gas sectors and, as analysis shows, they are hardly feasible. Moreover, if they were feasible, they would not be cooperation. Consequently, in the energy sector Lithuania should not overvalue the role of Poland and undervalue the other Baltic States, which have meaningful and promising relations with Lithuania.

\section{Bibliography}

\section{Legislation and Other Legal Documents}

1. Commission of the European Communities, Communication from The Commission to The Council and The European Parliament. Priority Interconnection Plan, $\operatorname{COM}(2006) 846$ final, 200701 10, http://dete.parliament.bg/pub/ECD/COM_2006_ 846_EN_ACTE_f.pdf, 20070802.

2. Commission of the European Communities, Commission Staff Working Document. EU Energy Policy Data, SEC(2007)12, 200710 10, http://ec.europa.eu/energy/energy_policy/doc/02_eu_energy_policy_data_en.pdf, 20070810.

3. European Commission, Directorate-General for Transport and Energy, Trans-European Energy Networks. 1st TEN-E Information Day, 200703 30, http://ec.europa. eu/ten/energy/documentation/doc/2007_03_30_ten_e_infoday_presentation_en.pdf, 20070815. 
4. Seimas of the Republic of Lithuania, Lietuvos Respublikos atominès elektrinés istatymas [Law of the Republic of Lithuania on nuclear power plant], X-1231, 200706 28, http://www3.lrs.lt/pls/inter3/dokpaieska.showdoc_l?p_id=301267, 20070710 (in Lithuanian).

5. Seimas of the Republic of Lithuania, Resolution on the Approval of the National Energy Strategy, No. X-1046, 200701 18, http://www3.lrs.lt/pls/inter3/dokpaieska. showdoc_1?p_id=292522, 20070901.

6. Government of the Republic of Lithuania, Nutarimas del Lietuvos Respublikos Vyriausybès 2006 metu veiklos ataskaitos pateikimo Lietuvos Respublikos Seimui [Resolution on submission of the report on activities of the Government of the Republic of Lithuania in 2006 to the Seimas of the Republic of Lithuania], No. 307, 200703 21, http://www.lrv.lt/14_vyr_dok/2006_veikl_atask.pdf, 20070904 (in Lithuanian).

7. The European Parliament and The Council Of The European Union, Decision of The European Parliament and of The Council. Laying Down Guidelines for Trans-European Energy Networks and Repealing Decision 96/391/EC and Decision No 1229/2003/ EC, No 1364/2006/EC, 200609 06, http://eur-lex.europa.eu/LexUriServ/site/en/ oj/2006/1_262/1_26220060922en00010023.pdf, 20070115.

8. Government of the Russian Federation, Энергетическая стратегия России на период до 2020 года [Russia's Energy strategy to 2020], No. 1234-p, 20030828. http://www.minprom.gov.ru/docs/strateg/1/print, 20061125 (in Russian).

\section{Documents of Companies}

1. AB "Klaipėdos nafta“, Metinis pranešimas 2006 m. [Annual report 2006], March 2007, http://www.oil.lt/uploads/media/Metinis_pranesimas_2006_patvirtintas.pdf, 20070705 (in Lithuanian).

2. AB "Lietuvos dujos", $2006 \mathrm{~m}$. konsoliduotas metinis pranešimas [Consolidated annual report 2006], http://www.vpk.lt/uploads/metinis_pranesimas_2006.pdf, 20070801 (in Lithuanian).

3. "AB "Mažeikių nafta“ 2006 metu prospektas-ataskaita [AB Mazeikiu Nafta folder-report 2006], www.nafta.lt/get_file.php?id=117, 20070705 (in Lithuanian).

4. Gassco and DNV, Information Concerning the Planning of the Skanled Gas Pipeline, June 2007, http://www.energinet.dk/NR/rdonlyres/E7D26121-FE5C-46C9-9DCB7BE95E65CD38/0/TheSkanledgaspipelineprojectsummaryver_02_250607.pdf, 2007 0905 .

5. OAO Gazprom, Annual Report 2006, http://www.gazprom.com/documents/Report Eng.pdf, 20070715.

6. Морской газопровод через Балтийское море (проект) [Maritime pipeline through the Baltic Sea (project)], http://www.mnr.gov.ru/part/?act=more\&id=1291\&pid=781, 20070715 (in Russian).

7. Nabucco Gas Pipeline International GmbH, Nabucco Gas Pipeline Project. Gas Bridge Between Caspian Region/ Middle East/ Egypt and Europe, February 2007, http://www.nabucco-pipeline.com/cms/upload/Partner_Logos/Nabucco_presentation_web_Feb_2007.pdf, 20070705.

8. Nabucco Project Description, http://www.nabucco-pipeline.com/project/project-description-pipeline-route/index.html, 20070705. 
9. Nabucco Project. Mission Statement/Strategic Goals, http://www.nabucco-pipeline. com/company/mission-statement-strategic-goals/index.html, 20070705.

10. Nord Stream, Project Information Document: Offshore Pipeline Through the Baltic Sea, November 2006, http://www.nord-stream.com/uploads/media/PID_ENGLISH_ 01.pdf, 20070722.

\section{Releases, Speeches, Interviews}

1. Ministry of the Foreign Affairs of the Republic of Lithuania, Lietuvos ir Lenkijos strategine partneryste igauna vis daugiau praktinių pavyzdžių [Strategic partnership of Lithuania and Poland gets even more examples of practical cooperation], 200606 13, http:// www.urm.lt/index.php?1080257421, 20070806 (in Lithuanian).

2. State of the Nation Address to the Seimas of the Republic of Lithuania by H.E. Mr. Valdas Adamkus, President of the Republic of Lithuania (2007), http://www.president. 1t/file/state_of_the_nation2007.pdf, 20070826.

\section{Monographs and Studies}

1. Baltic Maritime Outlook 2006. Goods Flows and Maritime Infrastructure in the Baltic Sea Region, March 2006, http://ec.europa.eu/transport/intermodality/motorways_sea/ doc/potential/2006_03_baltic_maritime_outlook.pdf, 20070205.

2. Deksnys R., Atominès elektrinès konkurencingumo Baltijos, Skandinavijos, Vakaru Europos šalių ir Rusijos elektros energijos rinkose analizè (galutinè ataskaita) [Analysis of competitiveness of nuclear power plant in the Baltic, Scandinavian, Western European and Russian markets (final report)], Department of Electric Power Systems at Faculty of Electrical engineering and control systems in Kaunas University of Technology, 20051201 (in Lithuanian).

3. European Commission, Directorate-General for Energy and Transport, European Energy and Transport Trends to 2030, 200301 30, http://ec.europa.eu/dgs/energy_ transport/figures/trends_2030/1_pref_en.pdf, 20070412.

4. European Commission, Directorate-General for Research, Energy Corridors. European Union and Neighbouring Countries, 2007, http:/www.ecn.nl/docs/library/report/2007/b07016.pdf, 20070820.

5. Joint UNDP/World Bank Energy Sector Management Assistance Programme, Russia Pipeline Oil Spill Study, April 2003, http://www.esmap.org/filez/pubs/ 03403RussiaPipelineOilSpillStudyReport.pdf, 20070205.

6. Ministry of Economy of the Republic of Lithuania, Tiekimo saugumas Lietuvos elektros energijos rinkoje. Monitoringo ataskaita [Security of supply in the electricity market of Lithuania. Report of monitoring], 2007, http://www.ena.lt/pdfai/Monitoringas_2007.pdf, 20070906 (in Lithuanian).

7. Panorama of the European Union. Gas and Electricity Market Statistics. 2006 Edition, Luxembourg: Office for Official Publications of the European Communities, 2006, http://ep.eurostat.ec.europa.eu/cache/ITY_OFFPUB/KS-76-06-289/EN/KS-76-06289-EN.pdf, 20070822.

8. Scheepers M., Seebregts A., Jong J., Maters H., EU Standards for Energy Security of Supply. Updates on the Crisis Capability Index and the Supply/Demand Index Quantification for EU-27, http://www.ecn.nl/docs/library/report/2007/e07004.pdf, 20070816. 
Articles in Scientific Periodicals, Collective Monographs, Internet Sites of Research Centres

1. Bassan M., "Electricity Statistics - Provisional data for 2006“. Eurostat Data in Focus, 4/2007. http://epp.eurostat.ec.europa.eu/cache/ITY_OFFPUB/KS-QA-07-004/EN/KSQA-07-004-EN.PDF, 20070802.

2. Jimenez A., "Statistical Aspects of the Natural Gas Economy in 2006", Eurostat Data in Focus, 14/2007, http://epp.eurostat.ec.europa.eu/cache/ITY_OFFPUB/KS-QA-07014/EN/KS-QA-07-014-EN.PDF, 20070810.

3. Kröppl C., "Oil Economy 2006“, Eurostat Data in Focus, 13/2007, http://epp.eurostat. ec.europa.eu/cache/ITY_OFFPUB/KS-QA-07-013/EN/KS-QA-07-013-EN.PDF, 20070823.

4. Naujos atominès elektrinès statybos Lietuvoje igyvendinamumo studijos rezultatu apibendrinimas [Summary of the results of the feasibility study on the construction of the new nuclear power plant in Lithuania], 200610 25, http://www.lpc.lt/repository/ Summary\%20Report\%20for\%20Media\%20-\%20LT.pdf, 20070813 (in Lithuanian).

5. Department of Statistics to the Government of the Republic of Lithuania, Energetikos statistika $2006 \mathrm{~m}$. [Energy statistics 2006], http://www.stat.gov.lt/lt/news/view/ ?id=1923, 20070620 (in Lithuanian).

6. The BP Statistical Review of World Energy 2007, http://www.bp.com/liveassets/ bp_internet/globalbp/globalbp_uk_english/reports_and_publications/statistical_energy_review_2007/STAGING/local_assets/downloads/spreadsheets/statistical_review_ full_report_workbook_2007.xls, 20070612.

7. UCTE, Statistical Yearbook 2005, http://www.ucte.org/_library/statsyearbook/Statistical_Yearbook_2005.pdf, 20070903.

\section{Articles in Periodicals, Reports of News Agencies, Radio Broadcasts, Opinions}

1. AFP, Russian Oil Supplies to Poland, Germany Caught in Belarus Dispute, 200701 08, http://www.breitbart.com/article.php?id=070108124819.kkhgowaq\&show_article=1, 20070205.

2. Alfa.lt, Lietuva ir Lenkija spartina energetini bendradarbiavimą [Lithuania and Poland accelerate energy cooperation], 200703 03, http://alfa.lt/straipsnis/127321, 200708 05 (in Lithuanian).

3. BNS, Europos Komisija paskyrè koordinatoriu energijos tilto iš Lietuvos į Lenkiją projektui [The European Commission appointed coordinator for the project of power bridge from Lithuania to Poland], 200709 13, http://www.euro.lt/lt/naujienos/apie-lietuvos-naryste-europos-sajungoje/naujienos/1471/?print=1, 20070913 (in Lithuanian).

4. BNS, Lietuvos ir Lenkijos elektros tiltas apsimokès, jei ES dengs 75 proc. investiciju [Power bridge of Lithuania and Poland will be feasible, if EU covers $75 \%$ of investments], 200707 31, http://www.euro.lt/lt/naujienos/apie-lietuvos-naryste-europos-sajungoje/naujienos/1219/, 20070802 (in Lithuanian).

5. BRE Bank Securities, PKN Orlen. Expansion to Lithuania, 200606 05, http://i.wp. pl/a/dibre/aspolek/pkn_050606_eng.pdf, 20070705. 
6. Chalupec I., "Mažeikių naftos" įsigijimas - stiprios regioninès grupès Centrinėje Europoje formavimas [Acquisition of Mazeikiu Nafta - creation of strong regional group in the Central Europe], 200612 15, http://www2.orlen.pl/pub/files/MN_Closing_IR_v15122006_LT.pdf, 20070705 (in Lithuanian).

7. Herron J., "Expansion Likely on Norway-Denmark Gas Pipeline", Dow Jones Newswires, 200709 07, http://www.downstreamtoday.com/News/ArticlePrint. aspx?aid=5854, 20070906.

8. Interfax, Polish PKN Orlen plans to merge with Lotos, no Warsaw listing for Czech Unipetrol, 200709 04, http://www.interfax.com/5/309376/news.aspx, 20070905.

9. Jeziorski M., "Alternative Access", The Warsaw Voice, 200601 18, http://www.warsawvoice.pl/view/10305, 20070810.

10. Juozaitis R., Ilgas lietuviškos elektros kelias i Vakarus [Long way of Lithuanian electricity to the West], http://neris.mii.lt/mt/straipsniai/20055/ilg.doc, 20070909 (in Lithuanian).

11. Komaras J.J., "Kodèl lenkai bijo rusų Mažeikiuose?" ["Why the Polish fear the Russians in Mazeikiai?’], Lrytas.lt, 200604 09, http://www.lrytas.lt/ ?id=11445789341142311187\&view=4, 20070825 (in Lithuanian).

12. Komaras J.J., "Lenko pozicija: kodèl nèra elektros tilto ì Vakarus?“" [Position of the Polish: why there is no power bridge to the West?]. Lrytas.lt, 200603 14, http://www. lrytas.lt/?id=11422625581141696756\&view=4, 20070115 (in Lithuanian).

13. Kubilius A., "Mažeikių nafta“ ir strateginè partnerystė su Lenkija [Mazeikiu Nafta and strategic partnership with Poland], 200612 18, http://www3.lrs.lt/pls/inter/w5 show?p_r=4932\&p_d=62373\&p_k=1, 20070903 (in Lithuanian).

14. Management Board of PGNiG selects the Location for LNG Terminal on the Polish Coast, http://www.en.pgnig.pl/cp/news/478_2208.htm, 20070810.

15. Naujos atominès elektrinès statyba. Projekto chronologija [Construction of the new nuclear power plant. Chronology of the project], http://www.lpc.lt/lt/main/atom/ Events_nuclear, 20070901 (in Lithuanian).

16. Newsru, “Дружба” врозь - правительство одобрило план строительства обходного нефтепровода [Druzhba smashed - government approved the plan of construction of bypassing pipeline], 200705 22, www.newsru.com/finance/ 22may2007/druzhba.html, 20070610 (in Russian).

17. Newsru, “Дружбе” конец: трубопровод в Литву не будет отремонтирован [The end of the Druzhba: pipeline to Lithuania will not be fixed ], 200709 07, http://www. newsru.com/finance/07sep2007/druzhba.html, 20070907 (in Russian).

18. Newsru, Россия может быстро построить трубу в обход Белоруссии и отказаться от поставок нефти в Литву [Russia can quickly build a pipeline bypassing Belarus and deny oil supply to Lithuania], 200702 13, www.newsru.com/finance/13feb2007/ vainshtock.html, 20070610 (in Russian).

19. Pakalkaitė V., "Lenkų bilietas ị Ignaliną - ir elektros tiltas" ["Ticket of the Polish to Ignalina - power bridge too"], Verslo žinios, 200701 09, http://vz.lt/Default2. aspx?ArticleID=79a120d9-7ac6-4912-a499-c129d1ab9edf, 20070215 (in Lithuanian). 
20. "PGNiG and Energinet.dk reached agreement on Baltic Pipe", Scandinavian Oil-Gas Magazine, http://www.scandoil.com/moxie-bm2/news/contracts_world/pgnig-andenerginetdk-rea.shtml, 20070906.

21. PGNiG to Acquire Stake in Norwegian Shelf Licences, http://www.rigzone.com/news/ article.asp?a_id=41995, 20070906.

22. PGNiG Will Acquire Hydrocarbon Reserves on the Norwegian Shelf, http://reakkt. wordpress.com/2007/03/01/pgnig-will-acquire-hydrocarbon-reserves-on-the-norwegian-shelf/, 20070906.

23. "PKN Orlen ambicijos“ [“Ambitions of PKN Orlen”], Versus, 200705 07, http:// www.lrytas.lt/?id=11785581771176340376\&view=4\&p=4, 20070905 (in Lithuanian).

24. "PKN Orlen" taikinys - "Klaipėdos nafta" ["Target of PKN Orlen - Klaipedos Nafta”], Balsas.lt, 200703 28, http://balsas.lt/naujienos/verslas/straipsnis68637, 200708 22 (in Lithuanian).

25. "Pokalbyje dèl naujos elektrinès - Lenkijos spaudimas" ["At the discussions on new power plant - Poland's pressure"], Bernardinai.lt, 200707 21, http://www.bernardinai. lt/index.php?url=articles/65476, 20070725 (in Lithuanian).

26. Poland Moves in New Directions Regarding Liquid Natural Gas Import, http://www. ilf.de/index.php?id=63\&L=1\&tx_ttnews\%5Btt_news\%5D=131\&tx_ttnews\%5BbackP id\%5D=18\&cHash=b675b13948, 20070810.

27. Polish Oil and Gas Company Joins Skanled Consortium, http://www.en.pgnig. pl/316_2414.htm, 20070906.

28. "Russian Oil Exports Down 1\%, Gas Exports 3\% in 2006 - Ministry", RIA Novosti, 200702 01, http://en.rian.ru/russia/20070201/60026020.html, 20070830.

29. Signing of a Letter of Intent Regarding the Construction of the Maritime Gas Terminal in the Port of Gdansk, http://www.portgdansk.pl/events/a-letter-of-intent-regardingthe-construction-of-the-lng-terminal, 20070810.

30. Tèvynès Sajunga, Rusijos sulaikymo strategija. Rusijos įtakos Lietuvoje mažinimo planas [Russia's containment strategy. Plan of reducing Russia's influence in Lithuania], 200705 09, http://www.visuomenei.lt/modules/document_publisher/documents/2/Rusijos\%20sulaikymo\%20strategijos\%20projektas\%2007\%2005\%2010.doc, 20070903 (in Lithuanian).

31. Watson C., "Denmark and Poland Considering Gas Pipeline", Energy Business Review Online. http://www.energy-business-review.com/article_news. asp?guid=464FFA34-5CEC-4DFA-A80C-5D0DC8312455, 20070906.

32. "Wintershall сделала предложение Польше" [“Wintershall made a proposal to Poland”], РБК daily, 200705 31, http://www.rbcdaily.ru/2007/05/31/tek/278103, 2007 0801 (in Russian).

33. "World Nuclear Review - Week Ending 21st July 2006", The Nuclear Communication Network, No.29/06. http://www.analys.se/lankar/Internat/NucNet/internatNucRew29_06.htm, 20070215.

34. Zhdannikov D., "Russia sets flat Q2 oil export schedule“. Reuters, 200703 21, http:// uk.reuters.com/article/oilRpt/idUKL213035720070321, 20070515. 
35. Баланс электроэнергии Калининградской энергосистемы на период до 2020 года [Balance of electricity in the energy system of Kaliningrad to 2020], http://impera. ru/region/economics/electricity, 20070604 (in Russian).

36. ИА Regnum, Вайншток: Стоимость проекта БТС-2 - около 2,5 млрд долларов [Vaynshtok: The cost of BPS-2 - about 2,5 billion dollars], 200706 10, www.regnum. ru/news/841614.html, 20070610 (in Russian).

37. “Калининградская ТЭЦ-2 полностью обеспечивает потребителей области собственной электроэнергией” [“Kaliningrad ТPР-2 completely supplies consumers of the district with its own electricity"], Press Release of Kaliningrad TPP-2, 200708 28, http://www.ktec2.net/index.php?type=555\&subcat=146, 20070901.

38. Нефтегазовые проекты. Одесса-Броды [Oil and gas projects. Odessa-Brody], www.oilcapital.ru/info/projects/63395/private/71862.shtml, 20070829 (in Russian).

39. Рагузина Г., Калининград стал заложником амбиций энергетического и газового гигантов [Kaliningrad became a hostage of ambitions of energy and gas giants], http://www.bellona.ru/articles_ru/chubais_tec, 20070623 (in Russian).

40. Успенский А., “Поляки требуют от "Газпрома” отдать долг.

41. EuRoPol GAZ подсчитала разницу в тарифах" [The Polish claim for dept from Gazprom. EuRoPol GAZ has counted difference in tariffs], РБК daily, 200701 17, http://pda.daily.rbc.ru/2007/01/17/tek/263467.shtml, 20070511 (in Russian).

\section{Maps}

1. $330 / 110 \mathrm{kV}$ perdavimo tinklas $[330 / 110 \mathrm{kV}$ transmission network], http://www.lietuvosenergija.lt/lt/main/system/network, 20070815 (in Lithuanian).

2. Gas Transmission Europe, Operational Procedures at major cross-border interconnection points, http://www.gie.eu.com/download/gridmap/GTE_OP_150.pdf, 20070716.

3. LNG Map. Information by Entry Point, http://www.gie.eu.com/download/gridmap/ GLE_LNG_207.pdf, 20070810.

4. Polish Energy Group, http://www.pse.pl/galeria/pge_01.jpg, 20070815.

5. Priority Projects for Electricity, http://ec.europa.eu/ten/energy/studies/doc/2004_brochure/electricity_network_07_en.jpg, 20070812. 